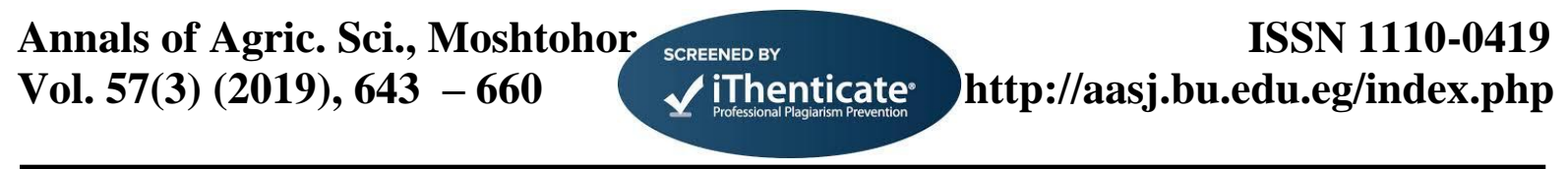

\title{
Maize Yield and the Associated Weeds as Affected by Plant Population Density and Weed Control Treatments
}

\author{
El-Saeed Mohamed Mahmoud El-Gedwy \\ Agronomy Department, Faculty of Agriculture, Benha University, Egypt \\ Corresponding author: alsaeed.algedwy@fagr.bu.edu.eg
}

\begin{abstract}
Two field experiments were carried out in the Farm of Agricultural Research and the Experimental Center of Faculty of Agriculture at Moshtohor, (Toukh Directorate, Qalyubia Governorate) Benha Univ. Egypt, during 2017 and 2018 seasons to investigate the effect of five plant population densities, i.e. 18, 21, 24, 27 and 30 thousand maize plants/feddan (fed) $\left\{\right.$ one fed $\left.=4200 \mathrm{~m}^{2}\right\}$ and five weed control treatments, i.e. pendimethalin $682.5 \mathrm{~g}$ a.i./fed (stomp extra $45.5 \% \mathrm{CS}$ ), acetochlor $840 \mathrm{~g}$ a.i./fed (harness $84 \% \mathrm{EC}$ ), nicosulfuron $24 \mathrm{~g}$ a.i./fed (active $6 \% \mathrm{SC}$ ), hand hoeing twice and the unweeded check (the control) on yield, some of its components and associated weeds in maize (single cross hybrid 2036 for Misr Hytech Seed Int.). Increasing plant population density from 18 to 30 thousand maize plants/fed reduced weed biomass at 50 days after sowing as well as significantly increased mean values of silking date, leaf area index at 80 days after sowing, plant height, ear height, No. of barren plants/fed, No. of ears/fed and stover yield/fed in both seasons. On the other hand, mean values of area of topmost ear leaf at 80 days after sowing, leaf area/plant at 80 days after sowing, stem diameter, No. of plants carried two ears/fed, ear length, No. of kernels/ear, weight of kernels/ear, shelling \%, 100-kernel weight and harvest index were significantly decreased in the two seasons. Maize planted at 24000 plants/fed produced the highest mean values of grain and biological yields/fed in both seasons. Weed control by hand hoeing twice or using nicosulfuron herbicide surpassed the other weed control treatments in depressing mean values of fresh and dry weights of broad-leaved, grassy and total annual weeds at 50 days after sowing maize, as well as gave the best mean values of all maize traits without significant difference between them. Maize planted at 30000 plants/fed under mechanical weed control (hand hoeing twice) or using nicosulfuron herbicide gave the lowest mean values of all weed measurements at 50 days after sowing as well as gave the greatest mean values of leaf area index, plant height, ear height, No. of ears/fed and stover yield/fed in both seasons. The greatest mean values of area of topmost ear leaf, leaf area/plant, No. of kernels/ear, weight of kernels/ear and 100-kernel weight were obtained from planting 18000 maize plants/fed with hand hoeing twice. Maize planted at 24000 plants/fed and hand hoeing twice produced the greatest mean values of biological yield/fed in both seasons. The maximum mean values of grain yield/fed were obtained by maize planted at 24000 and 21000 plants/fed and hand hoeing twice the first and second seasons, respectively. Planting maize by 21000 plants/fed with hand hoeing twice gave the highest mean values of nitrogen uptake/fed and protein yield/fed in both seasons.
\end{abstract}

Keywords: Maize, plant density, weed control, Pendimethalin, Acetochlor, nicosulfuron and hand hoeing

\section{Introduction}

Maize (Zea mays L.) is one of the most important cereal crops in the world and ranks the third of the most important cereal crops in the world which surpassed by wheat and rice. In Egypt, Maize is essential for livestocks and human consumption as an available source of carbohydrate, oil and slightly for protein. World average cultivated area of maize in 2017 year (www.fao.org) reached 469.49 million fed, the total production was 1134.75 million tonnes and an average productivity of $2416.97 \mathrm{~kg}$ grain/fed. The growing area of maize in Egypt was about 2.192 million fed with a total grain yield of 7.10 million tonnes by average grain yield was about 3239.19 $\mathrm{kg} / \mathrm{fed}$. The total production supplies $40-50 \%$ of the require consumption with a reduction gap of 50-60\% which has to be filled via importation.

As maize does not have tillering capacity to adjust to variation in plant stand, optimum plant population for grain production is important. Thus to increase grain yield, maize must be planted at proper population density. Fresh and dry weights of broadleaved, grassy and total annual weeds in maize fields were significantly decreased with increasing maize plant population density (Acciares and Zuluaga 2006; Abouziena et al. 2008; El-Gedwy et al. 2012; EL-Metwally et al. 2012; Teymoori et al. 2013; Amiri et al. 2014; El-Sobky and El-Naggar 2016 and Simić et al. 2017). Increasing maize plant population density significantly increased mean values of silking date, leaf area index, plant height, ear height, No. of barren plants/fed, No. of ears/fed, stover yield/fed. Vice-versa, significantly decreased mean values of area of topmost ear leaf, leaf area/plant, stem diameter, No. of plants carried two ears/fed, No. of ears/fed, ear length, No. of kernels/ear, weight of kernels/ear, kernels shelling \%, 100-kernel weight, harvest index, kernels nitrogen content and kernels crude protein content were significantly decreased. While, mean values of grain yield/fed, biological yield/fed, nitrogen uptake/fed 
and protein yield/fed were increased by increasing plant population density from lower plant density to optimum plant density then decreased (Abouziena $\boldsymbol{e t}$ al. 2008; EL-Metwally et al. 2012; El-Gedwy et al. 2012; Teymoori et al. 2013; Amiri et al. 2014; Marin and Weiner 2014; Gobeze et al. 2016; ElSobky and El-Naggar 2016; Mandić et al. 2016; Rahman et al. 2016; Sharanabasappa et al. 2017; Simić et al. 2017; Eyasu et al. 2018; Zeleke et al. 2018; El-Hosary et al. 2019; Ramesh Babu and Senthivel 2019; Sidi et al. 2019).

Excluding environmental variables, yield losses in corn are caused mainly by inter-specific competition with weeds. Weed interference is a severe problem in corn, especially in the early part of the growing season, due to slow early growth rate and wide row spacing. Weeds compete with the corn plants for resources such as light, nutrients, space, and moisture that influence the morphology and phenology of crop, reduce the yield, make harvesting difficult, and mar the quality of grains. Furthermore, high weed infestation increases the cost of cultivation, lowers value of land, and reduces the returns of corn producers. In order to realize the yield potential of corn, weed management becomes indispensable. A number of weed species compete with corn plant and have been observed to reduce yield as much as $46 \%$ with delay in weed control (El-Gedwy et al. 2012). Weed competition among the major constrains to crop production. Estimates of the worldwide loss potential in due to weeds, pathogens and animal pests in maize totaled by 40.3 , 9.4 and $16.0 \%$, respectively (Oerke, 2006). However, other researchers reported that losses in maize grain yield due to weed competition ranged between 74-90 \% (El-Gedwy et al. 2012 and Ramesh Babu \& Senthivel 2019). The allowing weeds to grow for whole growing season in maize significantly decreased all mean values of maize growth traits, yield components, yield and kernels properties compared with weed control by using hand hoeing or herbicides, vice versa, total fresh and dry weights of weeds were significantly increased (ElGedwy et al. 2012; Pacanoski et al. 2015; Tyagi et al. 2017; Simić et al. 2017 and Ramesh Babu \& Senthivel 2019). Several investigators showed that weed control by pendimethalin herbicides (Tahir $\boldsymbol{e t}$ al. 2009; Pacanoski et al. 2015; Shaban et al. 2015 and Shaban et al. 2016), acetochlor herbicides (Ahmed et al. 2008; EL-Metwally et al. 2012; Shaban et al. 2015; El-Sobky \& El-Naggar 2016; Shaban et al. 2016 and Tyagi et al. 2017), nicosulfuron herbicides (Knezevic et al. 2003; Rastgordani et al. 2013; Teymoori et al. 2013; Tesfay et al. 2014; Amare et al. 2015; Nogueira \& Correia 2016 and Simić et al. 2017) and hand hoeing (Abouziena et al. 2008; Ahmed et al. 2008; Tahir et al. 2009; El-Gedwy et al. 2012; ELMetwally et al. 2012; Rastgordani et al. 2013; Teymoori et al. 2013; Tesfay et al. 2014; Amare et al. 2015; Shaban et al. 2015; El-Sobky \& ElNaggar 2016; Shaban et al. 2016 and Ramesh Babu \& Senthivel 2019) were significantly depressed fresh and dry weights of weeds compared to the unweeded check as well as increased all mean values of maize.

Our objective in establishing this study was to determine the effects of different plant population density and weed control treatment on the associated weeds, growth traits, yield components, yield and kernels chemical properties of maize (single cross hybrid 2036 for Misr Hytech Seed Int.).

\section{Materials and Methods}

Two field experiments were carried out at the Farm of Agricultural Research and the Experimental Center of Faculty of Agriculture at Moshtohor, (Toukh Directorate, Qalyoubia Governorate) Benha Univ. Egypt, during the two summer successive growing seasons of 2017 and 2018 to investigate five plant population densities and five weed control treatments on the growth traits, yield components, yield and kernels chemical properties of maize (single cross hybrid 2036 for Misr Hytech Seed Int.) as well as associated weeds.

Soil texture of the experimental site was clay soil with a $\mathrm{pH}$ value of $8.12,8.16$ and $2.23 \%, 2.27 \%$ organic matter content during 2017 and 2018 seasons, respectively. The chemical and mechanical properties analysis of the experimental soil were determined according to the standard procedures described by Black and Evans (1965) and represented in Table 1 in each of the two growing seasons.

Table 1. Chemical and mechanical properties of the experimental soil units at planting maize during 2017 and 2018 seasons.

\begin{tabular}{lcc}
\hline \multirow{2}{*}{ Properties } & \multicolumn{2}{c}{ Seasons } \\
\cline { 2 - 3 } Chemical analysis & $\mathbf{2 0 1 7}$ & $\mathbf{2 0 1 8}$ \\
\hline E.C. & 2.26 & 2.23 \\
pH (1 :2.5) & 8.12 & 8.16 \\
CaCo3\% & 3.25 & 3.18 \\
O.M \% & 2.23 & 2.27 \\
N \% (total) & 0.21 & 0.23 \\
N (ppm) (available) & 65.11 & 67.02 \\
P \% (total) & 0.132 & 0.128 \\
P (ppm) (available) & 25.75 & 23.43 \\
K \% (total) & 0.66 & 0.67 \\
K (ppm) (available) & 897.06 & 925.98 \\
\hline Particle size distribution (mechanical analysis ) \\
\hline Course sand \% & 5.86 & 6.17 \\
Find sand \% & 28.25 & 27.84 \\
Silt \% & 14.62 & 13.26 \\
Clay \% & 51.27 & 52.73 \\
Texture grade & Clay & Clay \\
\hline
\end{tabular}

Factors under study were as follows: 


\section{A. Plant population densities were as follows:}

Five plant densities are tested. They are 18000, 21000, 24000, 27000 and 30000 maize plants/fed. Maize was grown in ridges $70 \mathrm{~cm}$. apart. The five densities were carried out as shown in Table 2.

Table 2. Plant density (plants/fed), No. of hills/4 m long of ridge and hills distance $(\mathrm{cm})$.

\begin{tabular}{lll}
\hline $\begin{array}{l}\text { Plant density } \\
\text { (plants/fed) }\end{array}$ & $\begin{array}{l}\text { No. of hills/4 } \mathbf{~ m} \\
\text { long of ridge }\end{array}$ & $\begin{array}{l}\text { Hills distance } \\
\text { (cm) }\end{array}$ \\
\hline $\mathbf{1 8 0 0 0}$ & 12 & 33.33 \\
$\mathbf{2 1 0 0 0}$ & 14 & 28.57 \\
$\mathbf{2 4 0 0 0}$ & 16 & 25.00 \\
$\mathbf{2 7 0 0 0}$ & 18 & 22.22 \\
$\mathbf{3 0 0 0 0}$ & 20 & 20.00 \\
\hline
\end{tabular}

B. Weed control treatment were as follows:

1. Pendimethalin (Stomp Extra $45.5 \%$ CS): N - (1 ethylpropyl) - 3,4 - dimethyl - 2,6 dinitrobenzenamine, applied as pre-emergence at the rate $682.5 \mathrm{~g}$ a.i./fed (one fed $=4200 \mathrm{~m}^{2}$ ).

2. Acetochlor (harness $84 \% \mathrm{EC}$ ): 2 - chloro - N (ethoxymethyl) - N - $(2$ - ethyl - 6 methylphenyl) acetamide, applied as preemergence at the rate $840 \mathrm{~g}$ a.i./fed.

3. Nicosulfuron (Active $6 \%$ SC): 2- [[[[[(4,6 dimethoxy - 2 - pyrimidinyl) amino] carbonyl] amino] sulfonyl] - N,N - dimethyl - 3 pyridinecarboxamide, applied as post-emergence at the rate $24 \mathrm{~g}$ a.i./fed.

4. Hand hoeing twice: at 15 and 30 days after sowing.

5. Unweeded check (the control).

All herbicides were sprayed using a knapsack sprayer equipped with one nozzle boom was used with spray volume of 200 liters/fed.

The preceding winter crop in the two seasons was wheat. The experimental design was laid out using randomized complete block design (RCBD) using split plot design in three replications. Each of the five plant densities were distributed in the main plots and the five treatments of weed control were assigned at random in sub plots. The sub plot area was $14.00 \mathrm{~m}^{2}$ and contained five ridges of $4.00 \mathrm{~m}$ long and $70 \mathrm{~cm}$ apart. Phosphorous fertilizer was applied in form of Calcium super phosphate $\left(12.5 \% \mathrm{P}_{2} \mathrm{O}_{5}\right)$ at a rate of $100 \mathrm{~kg} / \mathrm{fed}$ during soil preparation in each season. Experiments were planted on May $12^{\text {th }}$ and $15^{\text {th }}$ of in the first season (2017) and the second season (2018), respectively. Maize plants were thinned before the first irrigation to one plant/hill. Nitrogen fertilizer was applied at a rate of $150 \mathrm{~kg} \mathrm{~N} / \mathrm{fed}$ as urea $(46 \%$ $\mathrm{N})$, and divided into two equal parts and applied side dressed before the first and second irrigations in each season. The first irrigation was applied after 21 days from sowing and the following irrigations were applied at 10-15 days intervals during the growing seasons. Maize plants were harvested on $10^{\text {th }}$ and $14^{\text {th }}$ of September in the first and the second seasons, respectively. The other agricultural practices were kept the same as normally practiced in maize fields according to the recommendations of Ministry of Agriculture and Land Reclamation, except for the factors under study.

\section{Data recorded:}

\section{A. Weeds survey:-}

Annual weeds were manually pulled in a central area of square one meter area randomly placed from each sub plot after 50 days from sowing maize in each season and were identified and classified into annual broad-leaved and annual grassy weeds to estimate: fresh weight of broad-leaved weeds $(\mathrm{g})$, fresh weight of grassy weeds $(\mathrm{g})$ and total fresh weight of weeds $(\mathrm{g})$. Then dried on an air forced drying oven at $70^{0} \mathrm{c}$ for 72 hours to estimate: dry weight of broad-leaved weeds $(\mathrm{g})$, dry weight of grassy weeds ( $\mathrm{g}$ ) and total dry weight of weeds $(\mathrm{g})$.

\section{B. Maize traits:}

\section{I- Growth traits:}

Ten plants were chosen from the three center ridges at random from each sub plots to determine area of topmost ear leaf $\left(\mathrm{cm}^{2}\right)$ by Stickler 1964, leaf area/plant $\left(\mathrm{cm}^{2}\right)$, leaf area index [at 80 days after planting], plant height $(\mathrm{cm})$, ear height $(\mathrm{cm})$ and stem diameter $(\mathrm{cm})$ [at maize harvest]. Whereas, the silking date [No. of days from planting to $50 \%$ silking], No. of plants carried two ears/fed and No. of barren plants/fed [at maize harvest] were estimated from the whole plants in the sub plot.

\section{II- Yield and yield components:}

Ten ears were chosen from the three center ridges at random from each sub plots during maize harvest to determine ear length $(\mathrm{cm})$, No. of kernels/ear, weight of kernels/ear ( $\mathrm{g})$, kernels shelling (\%) and 100-kernel weight $(\mathrm{g})$. Whereas, No. of ears/fed, stover yield/fed $(\mathrm{kg})$, grain yield/fed $(\mathrm{kg})$, biological yield/fed $(\mathrm{kg})$ and harvest index $(\%)$ were estimated from the whole plants in the sub plots.

\section{Chemical analysis}

Maize kernels samples were taken after harvest at random from all kernels of ten ears to determine: nitrogen uptake/fed $(\mathrm{kg})=$ grain yield $(\mathrm{kg}) \mathrm{X}$ kernels nitrogen \% (modified micro Kjeldahl method, A. O. A. C., 1990)) and protein yield/fed $(\mathrm{kg})=$ nitrogen uptake/fed $(\mathrm{kg})$ X 6.25 .

\section{Statistical analysis:}

The analysis of variance was carried out according to the procedure described by Gomez and Gomez (1984). Data were statistically analyzed according to using the MSTAT-C Statistical Software Package (Michigan State University, 1983). Where the F-test showed significant differences among 
means L. S. D. test at 0.05 level was used to compare between means.

\section{Results and Discussion:}

\section{A- Weed survey :-}

The most dominant annual weeds in the experimental plots during the two seasons were represented by annual broad-leaved weeds as mexican fireplant (Euphorbia geniculata Ortega.), common purslane (Portulaca oleracea L.), jew's mallow (Corchorus olitorius L.), redroot pigweed (Amaranthus retroflexus L.), cocklebur (Xanthium strumarium L.), venice mallow (Hibiscus trionum L.) and prickly sida (Sida alba L.) as well as the annual grassy weeds as jungle rice $\{$ Echinochloa colonum (L.) Link. , viper grass $\{$ Dinebra retroflexa (Vahl.) Panz.\}, barnyard grass \{Echinochloa crus-galli (L.) Beauv. $\}$ and grain foxtail \{Setaria viridis (L.) Beauv.\}.

\section{1- Effect of plant population density:-}

Fresh and dry weights of broad-leaved, grassy and total annual weeds at 50 days after sowing maize were significantly reduced with every increase in plant population density up to 30000 plants/fed in both seasons (Table 3). No significance difference was shown among 18000 and 21000, 21000 and 24000 as well as 24000 and 27000 plants/fed on all weed measurements under study during both seasons. Results show that, the more denser maize plants, the more reduction in fresh and dry weights of broadleaved, grassy and total annual weeds at 50 days after sowing. The lowest mean values of fresh weight of broad-leaved weeds ( 335.88 and $\left.293.54 \mathrm{~g} / \mathrm{m}^{2}\right)$, fresh weight of grassy weeds (141.12 and $\left.130.78 \mathrm{~g} / \mathrm{m}^{2}\right)$, total fresh weight of weeds (477.00 and $424.32 \mathrm{~g} / \mathrm{m}^{2}$ ), dry weight of broad-leaved weeds (45.28 and 39.69 $\mathrm{g} / \mathrm{m}^{2}$ ), dry weight of grassy weeds (23.91 and 22.16 $\left.\mathrm{g} / \mathrm{m}^{2}\right)$ and total dry weight of weeds (69.19 and 61.85 $\mathrm{g} / \mathrm{m}^{2}$ ) which obtained from planting 30000 maize plants/fed in the 2017 and 2018 seasons, respectively. As well as, recorded the greatest mean values of control effect for annual broad-leaved weeds (16.27 and $19.79 \%$ ), annual grassy weeds (18.42 and 23.85 $\%)$ and total annual weeds (17.04 and $21.29 \%$ ) as compared with 18000 plants/fed in both seasons, respectively. Whereas, the highest mean values of fresh weight of broad-leaved weeds (401.28 and $\left.365.80 \mathrm{~g} / \mathrm{m}^{2}\right)$, fresh weight of grassy weeds $(173.46$ and $\left.170.22 \mathrm{~g} / \mathrm{m}^{2}\right)$, total fresh weight of weeds $(574.74$ and $536.02 \mathrm{~g} / \mathrm{m}^{2}$ ), dry weight of broad-leaved weeds $\left(54.08\right.$ and $\left.49.48 \mathrm{~g} / \mathrm{m}^{2}\right)$, dry weight of grassy weeds $\left(29.31\right.$ and $\left.29.10 \mathrm{~g} / \mathrm{m}^{2}\right)$ as well as total dry weight of weeds $\left(83.40\right.$ and $\left.78.58 \mathrm{~g} / \mathrm{m}^{2}\right)$ was obtained with growing 18000 maize plants/fed in the first and second season, respectively. The greatest reduction in weed biomass was achieved by sowing 30000 plants/fed during the two experimental seasons, where it decreased dry weight of annual broad-leaved weeds by $16.27 \%$ and $19.79 \%$ also dry weight of annual grassy weeds by $18.42 \%$ and $23.85 \%$ as well as total dry weight of annual weeds by $17.04 \%$ and $21.29 \%$ when compared with 18000 plants/fed in the first and second seasons, respectively. The gradual depression in weed biomass as plant population density of maize increased up to 30000 plants/fed may be due to inter and intra-specific competitions between maize plants and weeds plants for environmental factors (light, nutrient minerals, growth place and water). These results are in agreement with those reported by Acciares and Zuluaga 2006; Abouziena et al. 2008; El-Gedwy et al. 2012; EL-Metwally et al. 2012; Teymoori et al. 2013; Amiri et al. 2014; El-Sobky and El-Naggar 2016 and Simić et al. 2017.

\section{2- Effect of weed control treatments:-}

Results in Table 3 indicate that, hand hoeing twice and all herbicides treatments significantly depressed fresh and dry weights of weeds at 50 days after sowing compared to the unweeded check. No significantly difference was shown between nicosulfuron herbicide and hand hoeing twice on all weeds measurements under study during both seasons, as well as among pendimethalin and acetochlor herbicides on total fresh and dry weights of annual weeds in both seasons. Hand hoeing twice was the best treatment over all on depressed fresh and dry weights of weeds at 50 days after sowing during the two experimental seasons, where it gave the lowest mean values of fresh weight of broad-leaved weeds $\left(12.42\right.$ and $\left.13.60 \mathrm{~g} / \mathrm{m}^{2}\right)$, fresh weight of grassy weeds $\left(8.18\right.$ and $\left.11.08 \mathrm{~g} / \mathrm{m}^{2}\right)$, total fresh weight of weeds $\left(20.60\right.$ and $\left.24.68 \mathrm{~g} / \mathrm{m}^{2}\right)$, dry weight of broadleaved weeds $\left(1.70\right.$ and $\left.1.84 \mathrm{~g} / \mathrm{m}^{2}\right)$, dry weight of grassy weeds $\left(1.41\right.$ and $\left.1.91 \mathrm{~g} / \mathrm{m}^{2}\right)$ as well as total dry weight of weeds $\left(3.12\right.$ and $\left.3.74 \mathrm{~g} / \mathrm{m}^{2}\right)$ in 2017 and 2018 seasons, respectively. As well as, gave the maximum mean values of control effect for annual broad-leaved weeds (99.13 and $98.87 \%$ ), annual grassy weeds (98.66 and $97.93 \%$ ) and total annual weeds (98.96 and $98.53 \%$ ) as compared with unweeded control in both seasons, respectively. The next effective treatment against weeds biomass was nicosulfuron herbicide, where it decreased dry weight of annual broad-leaved weeds by $99.00 \%$ and 98.72 $\%$ and dry weight of annual grassy weeds by $98.50 \%$ and $97.68 \%$ as well as total dry weight of annual weeds by $98.82 \%$ and $98.34 \%$ compared with unweeded check at 50 days after sowing in 2017 and 2018 seasons, respectively. Fresh and dry weights of annual broad-leaved weeds as well as total weeds markedly reduced with using weed control treatments in a descending order; hand hoeing twice, nicosulfuron, acetochlor and pendimethalin herbicide. Meanwhile, fresh and dry weights of 
annual grassy weeds were significantly decreased with using control treatments in a descending order; hand hoeing twice, nicosulfuron, pendimethalin and acetochlor herbicide. Similar results were obtained by Knezevic et al. 2003; Abouziena et al. 2008; Ahmed et al. 2008; Tahir et al. 2009; El-Gedwy et al. 2012; EL-Metwally et al. 2012; Rastgordani et al. 2013; Teymoori et al. 2013; Tesfay et al. 2014; Amare et al. 2015; Pacanoski et al. 2015; Shaban et al. 2015; El-Sobky \& El-Naggar 2016; Nogueira \& Correia 2016; Shaban et al. 2016; Simić et al. 2017; Tyagi et al. 2017 as well as Ramesh Babu \& Senthivel 2019.

\section{3- Interaction effect between plant population density and weed control treatments:-}

Results in Table 4 show a significant interaction effect between plant population densities and weed control treatments on fresh and dry weights of broadleaved, grassy and total annual weeds in 2017 and 2018 seasons at 50 days after sowing maize. Results indicated that planting maize at a population density of 30000 plants/fed gave the greatest depression in all mean values of weed biomass with all weed control treatments. On the other hand, plant population density of 18000 plants/fed gave the lowest depression in all mean values under all weed control treatments in both growing seasons. Also, weed control by hand hoeing twice or using nicosulfuron herbicide gave the greatest depression in all mean values of weed biomass under all plant population densities in the first and second seasons. The lowest mean values of fresh weight of broad-leaved weeds $\left(10.2\right.$ and $\left.9.5 \mathrm{~g} / \mathrm{m}^{2}\right)$, fresh weight of grassy weeds $\left(5.7\right.$ and $\left.8.6 \mathrm{~g} / \mathrm{m}^{2}\right)$, total fresh weight of weeds (15.9 and $\left.18.1 \mathrm{~g} / \mathrm{m}^{2}\right)$, dry weight of broad-leaved weeds $\left(1.38\right.$ and $\left.1.28 \mathrm{~g} / \mathrm{m}^{2}\right)$, dry weight of grassy weeds $\left(1.01\right.$ and $\left.1.46 \mathrm{~g} / \mathrm{m}^{2}\right)$ as well as total dry weight of weeds $\left(2.39\right.$ and $2.74 \mathrm{~g} / \mathrm{m}^{2}$ ) in 2017 and 2018 seasons, respectively which obtained from plots under weed control by hand hoeing twice with maize planted at higher plant density (30000 plants/fed). These results are in agreement with those obtained by Acciares and Zuluaga 2006; Abouziena et al. 2008; El-Gedwy et al. 2012; EL-Metwally et al. 2012; Teymoori et al. 2013; Amiri et al. 2014; El-Sobky and El-Naggar 2016 and Simić et al. 2017.

\section{B- Maize traits:}

\section{I- Growth traits:}

1- Effect of plant population density:-

Mean values of all maize growth traits under study as affected by plant population densities in 2017 and 2018 seasons, are presented in Table 5. Results indicated that increasing plant population densities from 18000 up to 30000 plants/fed caused remarkable increments in mean values of No. of days from sowing to $50 \%$ silking, leaf area index, plant height $(\mathrm{cm})$, ear height $(\mathrm{cm})$ and No. of barren plants/fed during 2017 and 2018 seasons. On the other hand, mean values of area of topmost ear leaf $\left(\mathrm{cm}^{2}\right)$, leaf area/plant $\left(\mathrm{cm}^{2}\right)$, stem diameter $(\mathrm{cm})$ and No. of plants carried two ears/fed were significantly decreased by increasing maize plant population density in both seasons. Data revealed that planting maize at lowest plant density (18000 plants/fed) gave the greatest mean values of area of topmost ear leaf (769.36 and $786.26 \mathrm{~cm}^{2}$ ), leaf area/plant (9609.57 and $\left.9971.02 \mathrm{~cm}^{2}\right)$, stem diameter $(3.94$ and $4.05 \mathrm{~cm})$ and No. of plants carried two ears/fed (2820 and 2760 plants) as well as recorded the lowest mean values of No. of days to $50 \%$ silking (64.90 and 65.45 days), leaf area index (4.12 and 4.27), plant height $(291.45$ and $299.85 \mathrm{~cm})$, ear height $(137.30$ and $140.80 \mathrm{~cm}$ ) and No. of barren plants/fed (300 and 360 plants) in the first and second seasons, respectively. While, the greatest mean values of No. of days to $50 \%$ silking (67.00 and 68.95 days), leaf area index (5.08 and 5.01), plant height (326.10 and $336.70 \mathrm{~cm})$, ear height $(160.20$ and $165.40 \mathrm{~cm})$ and No. of barren plants/fed (3120 and 3060 plants) as well as the lowest mean values of area of topmost ear leaf (569.39 and $\left.554.80 \mathrm{~cm}^{2}\right)$, leaf area/plant (7114.46 and $\left.7017.93 \mathrm{~cm}^{2}\right)$, stem diameter (2.92 and $3.00 \mathrm{~cm}$ ) and No. of plants carried two ears/fed (zero) in the first and second seasons, respectively were obtained from maize planted at highest plant density (30000 plants/fed). Increasing population density from 18 to $21,24,27$ and 30 thousand plants/fed significantly increased plant height by $2.01,4.25$, 7.72 and $11.89 \%$ respectively, in the first season. The corresponding increases were $3.15,5.62,7.74$ and $12.29 \%$ in the second season for the respective densities. The increases in plant height by increasing plant densities is mainly due to the increased intraspecific competition among maize plants for light and decrease in light penetration, interception and photosynthetic efficiency at higher densities as well as higher dense of plants excessive shade exist which help to produce more content of gibberellin in tissues and consequently higher plants formed. These results are in harmony with those reported by Abouziena $\boldsymbol{e t}$ al. 2008; El-Gedwy et al. 2012; Amiri et al. 2014; Gobeze et al. 2016; Mandić et al. 2016; Simić et al. 2017; Eyasu et al. 2018; Zeleke et al. 2018 and Sidi et al. 2019. 
Table 3. Effect of plant population density and weed control treatments on mean values of fresh and dry weights of annual weeds $\left(\mathrm{g} / \mathrm{m}^{2}\right)$ at 50 days from sowing maize in 2017 and 2018 seasons.

\begin{tabular}{|c|c|c|c|c|c|c|c|c|c|}
\hline \multirow[b]{2}{*}{ Weed characters } & \multicolumn{3}{|c|}{ Fresh weight $\left(g / m^{2}\right)$} & \multicolumn{6}{|c|}{ Dry weight (g/m²) } \\
\hline & $\begin{array}{l}\text { Broad- } \\
\text { leaved } \\
\text { weeds }\end{array}$ & $\begin{array}{c}\text { Grassy } \\
\text { weeds }\end{array}$ & $\begin{array}{c}\text { Total } \\
\text { weeds }\end{array}$ & $\begin{array}{l}\text { Broad- } \\
\text { leaved } \\
\text { weeds }\end{array}$ & $\begin{array}{l}\text { Control } \\
\text { effect } \%\end{array}$ & $\begin{array}{c}\text { Grassy } \\
\text { weeds }\end{array}$ & $\begin{array}{l}\text { Control } \\
\text { effect } \%\end{array}$ & $\begin{array}{c}\text { Total } \\
\text { weeds }\end{array}$ & $\begin{array}{l}\text { Control } \\
\text { effect \% }\end{array}$ \\
\hline \multicolumn{10}{|c|}{ Plant population density } \\
\hline & \multicolumn{9}{|c|}{2017 season } \\
\hline 18000 plants/fed & 401.28 & 173.46 & 574.74 & 54.08 & -- & 29.31 & -- & 83.40 & -- \\
\hline 21000 plants/fed & 384.32 & 166.94 & 551.26 & 51.48 & 4.81 & 28.14 & 3.99 & 79.62 & 4.53 \\
\hline 24000 plants/fed & 370.72 & 161.14 & 531.86 & 50.15 & 7.27 & 27.14 & 7.40 & 77.29 & 7.33 \\
\hline 27000 plants/fed & 358.26 & 155.08 & 513.34 & 48.36 & 10.58 & 26.40 & 9.93 & 74.76 & 10.36 \\
\hline 30000 plants/fed & 335.88 & 141.12 & 477.00 & 45.28 & 16.27 & 23.91 & 18.42 & 69.19 & 17.04 \\
\hline \multirow[t]{2}{*}{ L.S.D at $5 \%$} & 20.65 & 11.75 & 30.44 & 2.99 & -- & 1.73 & -- & 4.52 & -- \\
\hline & \multicolumn{9}{|c|}{2018 season } \\
\hline 18000 plants/fed & 365.80 & 170.22 & 536.02 & 49.48 & -- & 29.10 & -- & 78.58 & -- \\
\hline 21000 plants/fed & 359.94 & 155.96 & 515.90 & 48.64 & 1.70 & 26.56 & 8.73 & 75.20 & 4.30 \\
\hline 24000 plants/fed & 349.52 & 149.58 & 499.10 & 47.20 & 4.61 & 25.39 & 12.75 & 72.58 & 7.64 \\
\hline 27000 plants/fed & 338.22 & 142.98 & 481.20 & 45.61 & 7.82 & 24.32 & 16.43 & 69.93 & 11.01 \\
\hline 30000 plants/fed & 293.54 & 130.78 & 424.32 & 39.69 & 19.79 & 22.16 & 23.85 & 61.85 & 21.29 \\
\hline L.S.D at $5 \%$ & 16.23 & 14.75 & 30.52 & 2.25 & -- & 2.06 & -- & 4.88 & -- \\
\hline \multicolumn{10}{|c|}{ Weed control treatments } \\
\hline & \multicolumn{9}{|c|}{2017 season } \\
\hline Pendimethalin & 260.64 & 53.52 & 314.16 & 35.18 & 81.99 & 9.15 & 91.30 & 44.33 & 85.25 \\
\hline Acetochlor & 111.58 & 103.44 & 215.02 & 15.20 & 92.22 & 17.59 & 83.28 & 32.79 & 89.09 \\
\hline Nicosulfuron & 14.34 & 9.18 & 23.52 & 1.96 & 99.00 & 1.58 & 98.50 & 3.54 & 98.82 \\
\hline Hand hoeing twice & 12.42 & 8.18 & 20.60 & 1.70 & 99.13 & 1.41 & 98.66 & 3.12 & 98.96 \\
\hline Unweeded check & 1451.48 & 623.42 & 2074.90 & 195.30 & -- & 105.18 & -- & 300.48 & -- \\
\hline \multirow[t]{2}{*}{ L.S.D at $5 \%$} & 71.56 & 32.51 & 118.25 & 10.25 & -- & 5.43 & -- & 18.29 & -- \\
\hline & \multicolumn{9}{|c|}{2018 season } \\
\hline Pendimethalin & 336.98 & 59.04 & 396.02 & 45.54 & 71.97 & 10.07 & 89.07 & 55.61 & 78.16 \\
\hline Acetochlor & 138.52 & 124.98 & 263.50 & 18.68 & 88.50 & 21.30 & 76.87 & 39.98 & 84.30 \\
\hline Nicosulfuron & 15.36 & 12.56 & 27.92 & 2.08 & 98.72 & 2.14 & 97.68 & 4.22 & 98.34 \\
\hline Hand hoeing twice & 13.60 & 11.08 & 24.68 & 1.84 & 98.87 & 1.91 & 97.93 & 3.74 & 98.53 \\
\hline Unweeded check & 1202.56 & 541.86 & 1744.42 & 162.49 & -- & 92.09 & -- & 254.58 & -- \\
\hline L.S.D at $5 \%$ & 64.54 & 36.56 & 105.72 & 9.04 & -- & 6.22 & -- & 16.39 & -- \\
\hline
\end{tabular}


Table 4. Effect of interaction between plant population density and weed control treatments on mean values of fresh and dry weights of annual weeds $\left(\mathrm{g} / \mathrm{m}^{2}\right)$ at 50 days from sowing maize during 2017 and 2018 seasons.

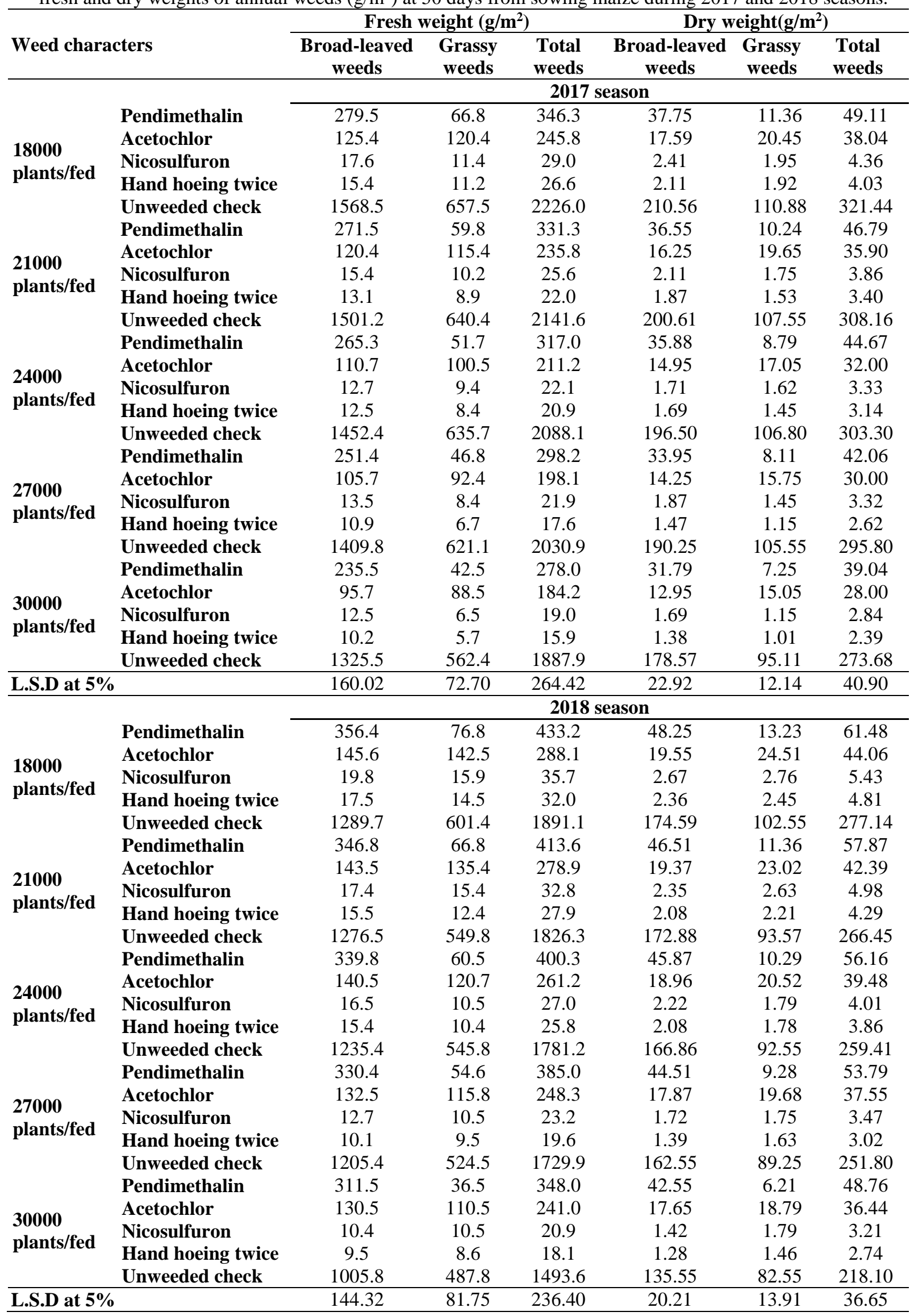




\section{2- Effect of weed control treatments:-}

Results presented in Table 5 showed that mean values of area of topmost ear leaf $\left(\mathrm{cm}^{2}\right)$, leaf area/plant $\left(\mathrm{cm}^{2}\right)$, leaf area index, plant height $(\mathrm{cm})$, ear height $(\mathrm{cm})$, stem diameter $(\mathrm{cm})$ and No. of plants carried two ears/fed were significant increased by using hand hoeing twice and all herbicides treatments compared to unweeded check except, mean values of No. of days from sowing to $50 \%$ silking and No. of barren plants/fed were significantly decreased during 2017 and 2018 seasons. But, No significantly difference was shown among pendimethalin, acetochlor, nicosulfuron and hand hoeing twice on No. of days from sowing to $50 \%$ silking, plant height, ear height and stem diameter during 2017 and 2018 seasons. Results show that weed control by hand hoeing twice recorded the maximum mean values of area of topmost ear leaf (715.61 and 736.00 $\mathrm{cm}^{2}$ ), leaf area/plant (9481.83 and $\left.10119.95 \mathrm{~cm}^{2}\right)$, leaf area index (5.31 and 5.64), plant height (330.10 and $342.05 \mathrm{~cm})$, ear height $(157.30$ and $162.95 \mathrm{~cm})$, stem diameter $(3.79$ and $3.86 \mathrm{~cm})$ and No. of plants carried two ears/fed (1680 and 1620 plants) as well as recorded the shortest period from planting to $50 \%$ silking (64.95 and 66.15 days) and gave lowest mean values of No. of barren plants/fed (600 and 660 plants) in the first and second seasons, respectively. The higher increases in mean values of plant leaf area were obtained with hand hoeing twice (63.80 and $78.48 \%$ ), nicosulfuron (56.79 and $66.65 \%)$, acetochlor $(53.95$ and $55.01 \%)$ followed by pendimethalin (48.58 and52.53\%) in 2017 and 2018 seasons, respectively over unweeded check. The increases in maize growth traits may be due to the good role of hand hoeing twice and herbicides treatments in depressed fresh and dry weights of weeds and decreased inter-specific competition among maize plants and weed plants. These results are in harmony with those reported by Knezevic $\boldsymbol{e t}$ al. 2003; Rastgordani et al. 2013; Teymoori et al. 2013; Tesfay et al. 2014; Amare et al. 2015; Nogueira \& Correia 2016 and Simić et al. 2017, who found that mean values of maize growth traits were increased as a result of using hand hoeing twice or some herbicidal treatments as nicosulfuron.

\section{3- Interaction effect between plant population density and weed control treatments:-}

Results in Table 6 show that the significant effect of the interaction among the five plant population densities, i.e. 18, 21, 24, 27 and 30 thousand maize plants/fed and the five weed control treatments (pendimethalin, acetochlor, nicosulfuron, hand hoeing twice and unweeded check) were obtained for mean values of area of topmost ear leaf $\left(\mathrm{cm}^{2}\right)$, leaf area/plant $\left(\mathrm{cm}^{2}\right)$, leaf area index, plant height $(\mathrm{cm})$ and ear height $(\mathrm{cm})$. Meanwhile, mean values of No. of days from sowing to $50 \%$ silking, stem diameter (cm), No. of plants carried two ears/fed and No. of barren plants/fed were not significantly affected by the interaction between plant population densities and weed control treatments during 2017 and 2018 seasons. Results indicated that planting maize at a population density of 18000 plants/fed gave the greatest mean values of area of topmost ear leaf and leaf area/plant as well as recorded the lowest mean values of leaf area index, plant height and ear height under all weed control treatments. Also, weed control by hand hoeing twice or using nicosulfuron herbicide gave the highest mean values of area of topmost ear leaf, leaf area/plant, leaf area index, plant height and ear height under all plant population densities in the first and second seasons. Results revealed that maize planted at higher plant density (30000 plants/fed) under weed control by hand hoeing twice recorded significantly the maximum values of leaf area index (5.78 and 5.90), plant height (351.25 and $365.75 \mathrm{~cm})$ and ear height $(172.25$ and $179.25 \mathrm{~cm})$ during 2017 and 2018 seasons, respectively. Meanwhile, the greatest mean values of area of topmost ear leaf $\left(825.75\right.$ and $\left.875.24 \mathrm{~cm}^{2}\right)$ and leaf area/plant (10941.19 and $12034.55 \mathrm{~cm}^{2}$ ) which were obtained from planting lower plant density (18000 plants/fed) under mechanical weed control by hand hoeing twice. Similar results were also reported by Abouziena et al. 2008; El-Gedwy et al. 2012; Amiri et al. 2014 and Simić et al. 2017.

\section{II- Yield and yield components: \\ 1- Effect of plant population density:-}

Results presented in Table 7 revealed that the differences between the studied five plant population densities, i.e. 18, 21, 24, 27 and 30 thousand maize plants/fed were significant on all mean values of yield components and yield during 2017 and 2018 seasons. But, there were no significant differences between planting 18000 and 21000 plants fed on mean values of shelling $\%$ and 100-kernels weight in both seasons and harvest index in the second season. Also, there was no significant difference between planting 21000 and 24000 plants/fed on mean values of 100-kernel weight and grain yield/fed. As well as, no significant difference among planting 27000 and 30000 plants/fed on mean values of biological yield/fed. Data revealed that planting 18000 maize plants/fed gave the greatest mean values of ear length (18.75 and $19.88 \mathrm{~cm})$, No. of kernels/ear (482.44 and 513.86 kernels), weight of kernels/ear (156.53 and $177.92 \mathrm{~g})$, kernels shelling (77.23 and $78.93 \%), 100$ kernel weight (31.66 and $33.78 \mathrm{~g}$ ) and harvest index ( 36.70 and $37.49 \%$ ) in the first and second seasons, respectively. In the 2017 season, planting maize at plant density of 18000 plants/fed increased No. of kernels/ear by $11.25,28.16,49.71$ and $82.58 \%$ also increased weight of kernels/ear by 13.63, 36.40, 70.81 and $125.78 \%$ compared with the growing maize at plant densities of 21000, 24000, 27000 and 30000 plants/fed respectively, the respective 
corresponding in the second season, were 8.14 , $25.03,39.15$ and $73.76 \%$ for No. of kernels/ear and by $12.72,34.48,60.48$ and $114.98 \%$ for weight of kernels/ear. This trend could be explained on the fact that in case of low population density produced by increasing hill spacing resulted in low intra-specific competition between it for nutrient elements, soil moisture and sun light, plants would have better opportunity to produce more metabolite contents and positive effect on plant growth and productivity as well as increased translocation and consequently accumulation of metabolites through kernels and gave the maximum values of plant traits and yield components. The greatest mean values of No. of ears/fed (26880 and 26940 ears) and stover yield/fed $(5173$ and $5370 \mathrm{~kg}$ ) which were obtained from planting 30000 maize plants/fed in the first and second seasons, respectively. Increasing population density from 18 to $21,24,27$ and 30 thousand plants/fed significantly increased stover yield/fed by $18.14,28.69,35.86$ and $45.57 \%$ respectively, in the first season. The corresponding increases were 15.08, $25.40,34.92$ and $42.06 \%$ in the second season for the respective densities. Such increase in stover yield/fed could be due to the increases in plant height, leaf area index and No. of plants/fed. Results showed that the optimum plant population density (24000 plants/fed) produced the highest mean values of grain yield/fed (2949.68 and $3219.89 \mathrm{~kg}$ ) and biological yield/fed ( 8445 and $8880 \mathrm{~kg}$ ) in the first and second seasons, respectively compared to the higher plant population (27000 and 30000 plants/fed) or the lower plants population (21000 and 18000 plants/ fed) in both seasons. These results reflect the important role of intra-specific competition between maize plants as plant density increased to reduce the yield till the optimum plant density is reached. On the other hand, the highest plant density (30000 plants/fed) produced the lowest grain yield/fed which were 1702.13 and $2008.95 \mathrm{~kg}$ in the first and second season, respectively. Meanwhile, the lowest plant density (18000 plants/fed) produced the lowest biological yield/fed which were 6870 and $7305 \mathrm{~kg}$ in the first and second season, respectively These results are in harmony with those reported by Acciares and Zuluaga 2006; El-Gedwy et al. 2012; Teymoori et al. 2013; Marin and Weiner 2014; El-Sobky and El-Naggar 2016; Rahman et al. 2016; Sharanabasappa et al. 2017 as well as Ramesh Babu and Senthivel 2019.

\section{2- Effect of weed control treatments:-}

Results presented in Table 7 showed that mean values of yield and yield components traits of maize significant increased when using hand hoeing twice or all herbicides treatments compared to unweeded check in the two growing seasons. Results may reveal the superiority of hand hoeing twice in mean values of No. of ears/fed (25080 and 24960 ears), ear length (17.48 and $19.01 \mathrm{~cm})$, No. of kernels/ear (441.50 and
486.71 kernels), weight of kernels/ear (141.85 and $165.37 \mathrm{~g}$ ), kernels shelling (77.76 and $79.58 \%$ ), 100kernel weight (31.66 and $33.51 \mathrm{~g})$, stover yield/fed (4920 and $5100 \mathrm{~kg}$ ), grain yield/fed (3008.39 and $3339.63 \mathrm{~kg})$, biological yield/fed (8775 and $9285 \mathrm{~kg})$ and harvest index (34.33 and $36.04 \%)$ during 2017 and 2018 seasons, respectively. Mean values of maize yield and its components increased under weed control treatments in ascending order; pendimethalin, acetochlor nicosulfuron and hand hoeing twice. But, there were no significant differences between nicosulfuron and hand hoeing twice and between pendimethalin and acetochlor as well as among acetochlor and nicosulfuron on mean values of allmost maize yield and yield components traits in the two growing seasons. The higher increases were obtained with hand hoeing twice (193.26 and 200.32 $\%$ ), nicosulfuron (179.76 and $192.00 \%$ ), acetochlor (167.43 and $180.08 \%)$ and followed by pendimethalin (159.82 and $167.63 \%$ ) in 2017 and 2018 seasons, respectively over the unweeded check (the control). The severe reduction in maize yield and its components when allowing weeds to compete maize plants could be attributed to inter-specific competition with the crop for light, water, nutrients and space which affected negatively the vegetative growth of plants particularly plant leaf area as well as dry matter accumulation. Moreover, some weeds shade the crop plants and then decrease the radiation that would fall on foliage of the crop. Consequently, this well affects negatively the photosynthesis efficiency and translocation of synthates to be stored in grain. As well as, may be due to the decrease in No. of ears/fed, ear length, No. of kernels/ear, weight of kernels/ear, shelling, 100-kernel weight and harvest index. The increases in seed yield/fed may be due to the good role of weed control by hand hoeing twice or using herbicides in improving and increasing yield attributes, i.e. No. of ears/fed, ear length, No. of kernels/ear, weight of kernels/ear, shelling, 100kernel weight and harvest index. These results are in harmony with those reported by Knezevic et al. 2003; Rastgordani et al. 2013; Teymoori et al. 2013; Tesfay et al. 2014; Amare et al. 2015; Nogueira \& Correia 2016 and Simić et al. 2017, who found that mean values of yield components traits and yield of maize were increased as a result of using hand hoeing twice or some herbicidal treatments as nicosulfuron. 
Table 5. Mean values of silking date, area of topmost ear leaf $\left(\mathrm{cm}^{2}\right)$, leaf area/plant $\left(\mathrm{cm}^{2}\right)$, leaf area index, plant height $(\mathrm{cm})$, ear height $(\mathrm{cm})$, stem diameter $(\mathrm{cm})$, No. of plants carried two ears/fed and No. of barren plants/fed of maize as affected by plant population density and weed control treatments during 2017 and 2018 seasons.

\begin{tabular}{|c|c|c|c|c|c|c|c|c|c|c|c|c|c|c|c|c|c|c|}
\hline \multirow{2}{*}{$\begin{array}{c}\text { Trait } \\
\text { Seasons }\end{array}$} & \multicolumn{2}{|c|}{ Silking date } & \multicolumn{2}{|c|}{$\begin{array}{c}\text { Area of } \\
\text { topmost ear } \\
\text { leaf }\left(\mathrm{cm}^{2}\right)\end{array}$} & \multicolumn{2}{|c|}{$\begin{array}{l}\text { Leaf area/plant } \\
\left(\mathrm{cm}^{2}\right)\end{array}$} & \multicolumn{2}{|c|}{$\begin{array}{l}\text { Leaf area } \\
\text { index }\end{array}$} & \multicolumn{2}{|c|}{$\begin{array}{l}\text { Plant height } \\
\text { (cm) }\end{array}$} & \multicolumn{2}{|c|}{$\begin{array}{l}\text { Ear height } \\
\quad(\mathrm{cm})\end{array}$} & \multicolumn{2}{|c|}{$\begin{array}{l}\text { Stem diameter } \\
(\mathrm{cm})\end{array}$} & \multicolumn{2}{|c|}{$\begin{array}{c}\text { No. of plants } \\
\text { carried two } \\
\text { ears/fed } \\
\end{array}$} & \multicolumn{2}{|c|}{$\begin{array}{l}\text { No. of barren } \\
\text { plants/fed }\end{array}$} \\
\hline & 2017 & 2018 & 2017 & 2018 & 2017 & 2018 & 2017 & 2018 & 2017 & 2018 & 2017 & 2018 & 2017 & 2018 & 2017 & 2018 & 2017 & 2018 \\
\hline \multicolumn{19}{|c|}{ Plant population density (plants/fed) } \\
\hline 18000 & 64.90 & 65.45 & 769.36 & 786.26 & 9609.57 & 9971.02 & 4.12 & 4.27 & 291.45 & 299.85 & 137.30 & 140.80 & 3.94 & 4.05 & 2820 & 2760 & 300 & 360 \\
\hline 21000 & 65.25 & 65.85 & 735.99 & 751.81 & 9195.87 & 9522.33 & 4.60 & 4.76 & 297.30 & 309.30 & 139.80 & 145.35 & 3.83 & 3.90 & 1860 & 1920 & 480 & 420 \\
\hline 24000 & 65.80 & 67.00 & 669.26 & 666.69 & 8356.91 & 8445.29 & 4.78 & 4.83 & 303.85 & 316.70 & 142.95 & 149.10 & 3.65 & 3.71 & 1020 & 1140 & 900 & 960 \\
\hline 27000 & 66.25 & 68.00 & 608.69 & 610.40 & 7581.88 & 7720.08 & 4.87 & 4.96 & 313.95 & 323.05 & 150.75 & 155.10 & 3.39 & 3.41 & 120 & 240 & 1680 & 1680 \\
\hline 30000 & 67.00 & 68.95 & 569.39 & 554.80 & 7114.46 & 7017.93 & 5.08 & 5.01 & 326.10 & 336.70 & 160.20 & 165.40 & 2.92 & 3.00 & 0 & 0 & 3120 & 3060 \\
\hline L.S.D at $5 \%$ & 0.82 & 0.89 & 26.54 & 38.51 & 342.11 & 481.55 & 0.12 & 0.17 & 6.72 & 8.12 & 4.12 & 4.98 & 0.10 & 0.11 & 54 & 48 & 61 & 52 \\
\hline \multicolumn{19}{|c|}{ Weed control treatments } \\
\hline Pendimethalin & 65.90 & 67.00 & 674.56 & 678.33 & 8600.69 & 8648.66 & 4.82 & 4.83 & 323.50 & 333.15 & 154.05 & 158.70 & 3.64 & 3.76 & 1260 & 1380 & 1200 & 1080 \\
\hline Acetochlor & 65.50 & 66.70 & 685.51 & 689.33 & 8911.60 & 8789.01 & 4.99 & 4.91 & 326.10 & 334.05 & 155.40 & 159.10 & 3.69 & 3.79 & 1380 & 1500 & 960 & 900 \\
\hline Nicosulfuron & 65.05 & 66.30 & 698.16 & 713.13 & 9076.03 & 9449.03 & 5.09 & 5.27 & 328.30 & 339.30 & 156.40 & 161.65 & 3.73 & 3.81 & 1500 & 1560 & 780 & 780 \\
\hline Hand hoeing twice & 64.95 & 66.15 & 715.61 & 736.00 & 9481.83 & 10119.95 & 5.31 & 5.64 & 330.10 & 342.05 & 157.30 & 162.95 & 3.79 & 3.86 & 1680 & 1620 & 600 & 660 \\
\hline Unweeded check & 67.80 & 69.10 & 578.85 & 553.17 & 5788.54 & 5670.01 & 3.25 & 3.18 & 224.65 & 237.05 & 107.85 & 113.35 & 2.88 & 2.86 & 0 & 0 & 2940 & 3060 \\
\hline L.S.D at 5\% & 0.96 & 0.98 & 29.23 & 39.54 & 401.23 & 498.33 & 0.21 & 0.28 & 11.25 & 13.41 & 6.52 & 7.84 & 0.16 & 0.18 & 65 & 57 & 83 & 75 \\
\hline
\end{tabular}


Table 6. Mean values of silking date, area of topmost ear leaf $\left(\mathrm{cm}^{2}\right)$, leaf area/plant $\left(\mathrm{cm}^{2}\right)$, leaf area index, plant height $(\mathrm{cm})$, ear height $(\mathrm{cm})$, stem diameter $(\mathrm{cm})$, No. of plants carried two ears/fed and No. of barren plants/fed of maize as affected by interaction between plant population density and weed control treatments during 2017 and 2018 seasons.

\begin{tabular}{|c|c|c|c|c|c|c|c|c|c|c|c|c|c|c|c|c|c|c|c|}
\hline \multirow{2}{*}{$\begin{array}{l}\text { Trait } \\
\text { Season } \\
\end{array}$} & & \multicolumn{2}{|c|}{ Silking date } & \multicolumn{2}{|c|}{$\begin{array}{l}\text { area of topmost } \\
\text { ear leaf }\left(\mathrm{cm}^{2}\right)\end{array}$} & \multicolumn{2}{|c|}{$\begin{array}{l}\text { leaf area/plant } \\
\left(\mathrm{cm}^{2}\right)\end{array}$} & \multicolumn{2}{|c|}{$\begin{array}{l}\text { leaf area } \\
\text { index }\end{array}$} & \multicolumn{2}{|c|}{$\begin{array}{l}\text { Plant height } \\
\text { (cm) }\end{array}$} & \multicolumn{2}{|c|}{ Ear height $(\mathrm{cm})$} & \multicolumn{2}{|c|}{$\begin{array}{l}\text { Stem diameter } \\
(\mathbf{c m})\end{array}$} & \multicolumn{2}{|c|}{$\begin{array}{c}\text { No. of plants } \\
\text { carried two } \\
\text { ears/fed }\end{array}$} & \multicolumn{2}{|c|}{$\begin{array}{l}\text { No. of barren } \\
\text { plants/fed }\end{array}$} \\
\hline & & 2017 & 2018 & 2017 & 2018 & 2017 & 2018 & 2017 & 2018 & 2017 & 2018 & 2017 & 2018 & 2017 & 2018 & 2017 & 2018 & 2017 & 2018 \\
\hline \multirow{5}{*}{$\begin{array}{l}18000 \\
\text { plants/fed }\end{array}$} & Pendimethalin & 64.75 & 65.25 & 776.85 & 793.25 & 9904.84 & 10113.94 & 4.24 & 4.33 & 308.75 & 312.25 & 145.00 & 146.75 & 4.11 & 4.25 & 3300 & 3300 & 0 & 0 \\
\hline & Acetochlor & 64.50 & 64.75 & 786.36 & 804.75 & 10222.68 & 10260.56 & 4.38 & 4.40 & 310.25 & 315.25 & 146.00 & 148.25 & 4.15 & 4.29 & 3300 & 3300 & 0 & 0 \\
\hline & Nicosulfuron & 64.25 & 64.50 & 800.25 & 833.57 & 10403.25 & 11044.80 & 4.46 & 4.73 & 312.25 & 320.75 & 146.75 & 150.75 & 4.23 & 4.32 & 3600 & 3600 & 0 & 0 \\
\hline & Hand hoeing twice & 64.00 & 64.50 & 825.75 & 875.24 & 10941.19 & 12034.55 & 4.69 & 5.16 & 315.75 & 325.50 & 148.50 & 153.00 & 4.25 & 4.39 & 3900 & 3600 & 0 & 0 \\
\hline & Unweeded check & 67.00 & 68.25 & 657.59 & 624.51 & 6575.90 & 6401.23 & 2.82 & 2.74 & 210.25 & 225.50 & 100.25 & 105.25 & 2.98 & 3.02 & 0 & 0 & 1500 & 1800 \\
\hline \multirow{5}{*}{$\begin{array}{l}21000 \\
\text { plants/fed }\end{array}$} & Pendimethalin & 65.00 & 65.50 & 744.23 & 751.24 & 9488.93 & 9578.31 & 4.74 & 4.79 & 316.25 & 326.50 & 148.75 & 153.50 & 4.02 & 4.11 & 2100 & 2400 & 300 & 0 \\
\hline & Acetochlor & 64.75 & 65.25 & 756.91 & 768.72 & 9839.83 & 9801.18 & 4.92 & 4.90 & 318.25 & 327.75 & 149.75 & 154.00 & 4.03 & 4.12 & 2400 & 2400 & 0 & 0 \\
\hline & Nicosulfuron & 64.50 & 64.75 & 765.81 & 799.82 & 9955.53 & 10597.62 & 4.98 & 5.30 & 319.00 & 330.00 & 150.00 & 155.00 & 4.07 & 4.13 & 2100 & 2400 & 0 & 0 \\
\hline & Hand hoeing twice & 64.50 & 64.75 & 789.25 & 823.50 & 10457.56 & 11323.13 & 5.23 & 5.66 & 319.25 & 330.75 & 150.00 & 155.50 & 4.10 & 4.20 & 2700 & 2400 & 0 & 0 \\
\hline & Unweeded check & 67.50 & 69.00 & 623.75 & 615.75 & 6237.50 & 6311.44 & 3.12 & 3.16 & 213.75 & 231.50 & 100.50 & 108.75 & 2.95 & 2.94 & 0 & 0 & 2100 & 2100 \\
\hline \multirow{5}{*}{$\begin{array}{l}24000 \\
\text { plants/fed }\end{array}$} & Pendimethalin & 66.25 & 67.00 & 667.24 & 671.25 & 8507.31 & 8558.44 & 4.86 & 4.89 & 320.75 & 333.25 & 150.75 & 156.75 & 3.75 & 3.88 & 900 & 1200 & 600 & 600 \\
\hline & Acetochlor & 65.50 & 66.25 & 689.78 & 678.25 & 8967.14 & 8647.69 & 5.12 & 4.94 & 323.50 & 336.75 & 152.00 & 158.25 & 3.82 & 3.91 & 1200 & 1500 & 600 & 300 \\
\hline & Nicosulfuron & 64.50 & 66.50 & 700.69 & 715.47 & 9108.97 & 9479.98 & 5.21 & 5.42 & 325.25 & 337.50 & 152.75 & 158.75 & 3.85 & 3.92 & 1500 & 1500 & 300 & 300 \\
\hline & Hand hoeing twice & 64.75 & 66.25 & 712.35 & 725.24 & 9438.64 & 9972.05 & 5.39 & 5.70 & 326.50 & 338.75 & 153.50 & 159.25 & 3.91 & 3.95 & 1500 & 1500 & 0 & 300 \\
\hline & Unweeded check & 68.00 & 69.00 & 576.25 & 543.25 & 5762.50 & 5568.31 & 3.29 & 3.18 & 223.25 & 237.25 & 105.75 & 112.50 & 2.92 & 2.90 & 0 & 0 & 3000 & 3300 \\
\hline \multirow{5}{*}{$\begin{array}{l}27000 \\
\text { plants/fed }\end{array}$} & Pendimethalin & 66.50 & 68.25 & 610.25 & 615.75 & 7780.69 & 7850.81 & 5.00 & 5.05 & 329.25 & 340.50 & 158.00 & 163.50 & 3.45 & 3.50 & 0 & 0 & 1500 & 1500 \\
\hline & Acetochlor & 66.00 & 68.25 & 613.24 & 625.24 & 7972.12 & 7971.81 & 5.12 & 5.12 & 332.75 & 334.75 & 159.75 & 160.75 & 3.49 & 3.53 & 0 & 300 & 1200 & 1500 \\
\hline & Nicosulfuron & 65.50 & 67.25 & 625.46 & 640.00 & 8130.98 & 8480.00 & 5.23 & 5.45 & 335.50 & 346.75 & 161.25 & 166.50 & 3.51 & 3.55 & 300 & 300 & 1200 & 900 \\
\hline & Hand hoeing twice & 65.25 & 66.75 & 640.25 & 655.75 & 8483.31 & 9016.56 & 5.45 & 5.80 & 337.75 & 349.50 & 162.25 & 167.75 & 3.65 & 3.64 & 300 & 600 & 900 & 600 \\
\hline & Unweeded check & 68.00 & 69.50 & 554.23 & 515.24 & 5542.30 & 5281.21 & 3.56 & 3.40 & 234.50 & 243.75 & 112.50 & 117.00 & 2.86 & 2.81 & 0 & 0 & 3600 & 3900 \\
\hline \multirow{5}{*}{$\begin{array}{l}30000 \\
\text { plants/fed }\end{array}$} & Pendimethalin & 67.00 & 69.00 & 574.25 & 560.14 & 7321.69 & 7141.79 & 5.23 & 5.10 & 342.50 & 353.25 & 167.75 & 173.00 & 2.89 & 3.05 & 0 & 0 & 3600 & 3300 \\
\hline & Acetochlor & 66.75 & 69.00 & 581.25 & 569.71 & 7556.25 & 7263.80 & 5.40 & 5.19 & 345.75 & 355.75 & 169.50 & 174.25 & 2.95 & 3.08 & 0 & 0 & 3000 & 2700 \\
\hline & Nicosulfuron & 66.50 & 68.50 & 598.57 & 576.81 & 7781.41 & 7642.73 & 5.56 & 5.46 & 349.50 & 361.50 & 171.25 & 177.25 & 3.00 & 3.11 & 0 & 0 & 2400 & 2700 \\
\hline & Hand hoeing twice & 66.25 & 68.50 & 610.45 & 600.25 & 8088.46 & 8253.44 & 5.78 & 5.90 & 351.25 & 365.75 & 172.25 & 179.25 & 3.05 & 3.11 & 0 & 0 & 2100 & 2400 \\
\hline & Unweeded check & 68.50 & 69.75 & 482.45 & 467.11 & 4824.50 & 4787.88 & 3.45 & 3.42 & 241.50 & 247.25 & 120.25 & 123.25 & 2.71 & 2.63 & 0 & 0 & 4500 & 4200 \\
\hline \multicolumn{2}{|c|}{ L.S.D at $5 \%$} & N.S. & N.S. & 65.36 & 88.41 & 897.18 & 1114.30 & 0.47 & 0.63 & 25.16 & 29.99 & 14.58 & 17.53 & N.S. & N.S. & N.S. & N.S. & N.S. & N.S. \\
\hline
\end{tabular}


Table 7. Mean values of No. ears/fed, ear length (cm), No. of kernels/ear, weight of kernels/ear(g), shelling \%, 100-kernel weight (g), stover yield/fed (kg), grain yield/fed $(\mathrm{kg})$, biological yield/fed $(\mathrm{kg})$ and harvest index $(\%)$ as affected by plant population density and weed control treatments during 2017 and 2018 seasons.

\begin{tabular}{|c|c|c|c|c|c|c|c|c|c|c|c|c|c|c|c|c|c|c|c|c|}
\hline \multirow{2}{*}{$\begin{array}{l}\text { Trait } \\
\text { Seasons }\end{array}$} & \multicolumn{2}{|c|}{$\begin{array}{c}\text { No. of } \\
\text { ears/fed }\end{array}$} & \multicolumn{2}{|c|}{$\begin{array}{l}\text { ear length } \\
\quad(\mathrm{cm})\end{array}$} & \multicolumn{2}{|c|}{$\begin{array}{c}\text { No. of } \\
\text { kernels/ear }\end{array}$} & \multicolumn{2}{|c|}{$\begin{array}{l}\text { Weight of } \\
\text { kernels/ear } \\
\text { (g) }\end{array}$} & \multicolumn{2}{|c|}{ Shelling \% } & \multicolumn{2}{|c|}{$\begin{array}{l}\text { 100-kernel } \\
\text { weight (g) }\end{array}$} & \multicolumn{2}{|c|}{$\begin{array}{c}\text { Stover } \\
\text { yield/fed } \\
(\mathbf{k g})\end{array}$} & \multicolumn{2}{|c|}{$\begin{array}{c}\text { Grain yield/fed } \\
(\mathbf{k g})\end{array}$} & \multicolumn{2}{|c|}{$\begin{array}{c}\text { Biological } \\
\text { yield/fed }(\mathrm{kg})\end{array}$} & \multicolumn{2}{|c|}{$\begin{array}{l}\text { Harvest } \\
\text { index } \%\end{array}$} \\
\hline & 2017 & 2018 & 2017 & 2018 & 2017 & 2018 & 2017 & 2018 & 2017 & 2018 & 2017 & 2018 & 2017 & 2018 & 2017 & 2018 & 2017 & 2018 & 2017 & 2018 \\
\hline \multicolumn{21}{|c|}{ Plant population density (plants/fed) } \\
\hline 18000 & 20520 & 20400 & 18.75 & 19.88 & 482.44 & 513.86 & 156.53 & 177.92 & 77.23 & 78.93 & 31.66 & 33.78 & 3555 & 3780 & 2617.35 & 2845.03 & 6870 & 7305 & 36.70 & 37.49 \\
\hline 21000 & 22380 & 22500 & 17.11 & 18.39 & 433.66 & 475.16 & 137.75 & 157.84 & 76.62 & 78.24 & 31.08 & 32.49 & 4200 & 4350 & 2838.49 & 3184.97 & 7830 & 8340 & 35.12 & 36.96 \\
\hline 24000 & 24120 & 24180 & 15.92 & 17.18 & 376.45 & & 114.76 & 132.30 & 74.71 & 76.21 & 29.81 & 31.48 & 4575 & 4740 & 2949.68 & 3219.89 & 8445 & 8880 & 33.92 & 35.15 \\
\hline 27000 & 25440 & 25560 & 14.24 & 15.48 & 322.24 & 369.28 & 91.64 & 110.87 & 73.25 & 74.50 & 27.81 & 29.34 & 4830 & 5100 & 2205.11 & 2530.52 & 7785 & 8430 & 27.49 & 29.10 \\
\hline 30000 & 26880 & 26940 & 12.76 & 14.37 & 264.23 & 295.73 & 69.33 & 82.76 & 70.53 & 72.11 & 25.87 & 27.46 & 5175 & 5370 & 1702.13 & 2008.95 & 7560 & 8115 & 22.14 & 24.19 \\
\hline L.S.D at $5 \%$ & 112 & 120 & 0.85 & 0.76 & 26.51 & 20.15 & 10.25 & 8.87 & 1.23 & 0.98 & 1.43 & 1.32 & 216 & 198 & 156.98 & 142.72 & 356 & 312 & 0.98 & 0.75 \\
\hline
\end{tabular}

Weed control treatments

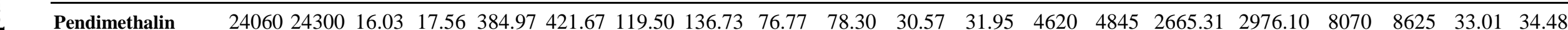

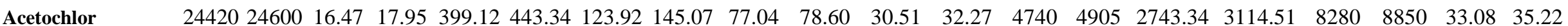

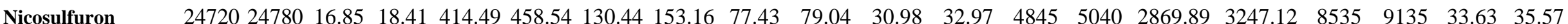

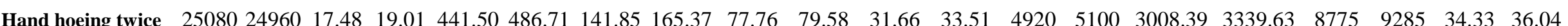

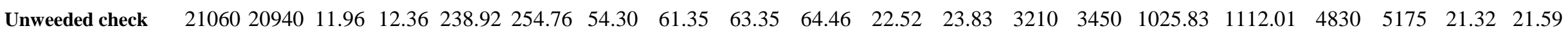

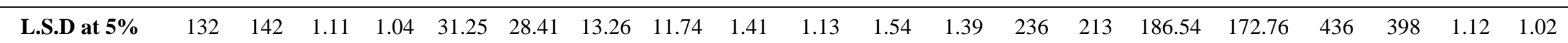




\section{3- Interaction effect between plant population density and weed control treatments:-}

Results in Table 8 clear that mean values of No. of ears/fed, No. of kernels/ear, weight of kernels/ear, 100-kernel weight, stover yield/fed, grain yield/fed and biological yield/fed were significantly affected by the interaction between plant population densities and weed control treatments. While, mean values of ear length, shelling $\%$ and harvest index were not significantly affected by the interaction during 2017 and 2018 seasons. Results showed that maize planed at lower plant density (18000 plants/fed) under mechanical weed control (hand hoeing twice) gave the maximum mean values of No. of kernels/ear (574.20 and 619.08 kernels), weight of kernels/ear (198.21 and $229.37 \mathrm{~g}), 100$-kernel weight (34.52 and $37.05 \mathrm{~g}$ ) in the first and second seasons, respectively. The maximum mean values of No. of ears/fed (27900 and 27600 ears) and stover yield/fed $(5700$ and $5775 \mathrm{~kg})$ in the first and second seasons, respectively which were obtained from higher plant density (30000 plants/fed) with hand hoeing twice for weed control. Maize planted at 24000 plants/fed under weed control by hand hoeing twice produced the greatest mean values of biological yield/fed $(9375$ and $9975 \mathrm{~kg}$ ) in the first and second season. The maximum mean values of grain yield/fed (3458.14 and $3798.12 \mathrm{~kg}$ ) were obtained from maize planted at 24000 and 21000 plants/fed under hand hoeing twice for weed control the first and second seasons, respectively. These results agree with those reported by Acciares and Zuluaga 2006; El-Gedwy et al. 2012; Teymoori et al. 2013 as well as El-Sobky and ElNaggar 2016.

\section{C- Chemical analysis: \\ 1- Effect of plant population density:-}

Results in Table 9 show that plant density significantly affected mean values of nitrogen uptake/fed $(\mathrm{kg})$ and protein yield/fed $(\mathrm{kg})$. While, mean values of kernels nitrogen content $(\%)$ and kernels crude protein content (\%) were not significantly affected by maize plant density in 2017 and 2018 seasons. In the first season, the highest mean values of nitrogen uptake/fed (56.61 $\mathrm{kg})$ and protein yield/fed $(353.82 \mathrm{~kg})$ were detected with maize planting by 24000 plants/ fed. While, in the second season, maize planting at 21000 plants/fed gave the greatest mean values of nitrogen uptake/fed $(61.25 \mathrm{~kg})$ and protein yield/fed (382.84 $\mathrm{kg})$. However, the highest plant density $(30000$ plants/fed) gave the lowest nitrogen uptake/fed $(30.03$ and $34.95 \mathrm{~kg})$ and protein yield/fed (187.71 and $218.47 \mathrm{~kg}$ ) in the first and second seasons, respectively. No significant difference was found between planting 21000 and 24000 plants/fed on mean values of nitrogen uptake/fed $(\mathrm{kg})$ and protein yield/fed $(\mathrm{kg})$. This result may be due to the increase in grain yield/fed. The results agree with those reported by El-Gedwy et al. 2012; ELMetwally et al. 2012; El-Sobky and El-Naggar 2016 and El-Hosary et al. 2019.

\section{2- Effect of weed control treatments:-}

Results in Table 9 showed that mean values of nitrogen uptake/fed $(\mathrm{kg})$ and protein yield/fed $(\mathrm{kg})$ were significantly influenced by weed control treatments. But, mean values of kernels nitrogen content (\%) and kernels crude protein content (\%) were not significantly affected by weed control treatments in the first and second season. Planting maize with weeds controlling by hand hoeing twice recoded maximum mean values of nitrogen uptake/fed (59.15 and $63.57 \mathrm{~kg})$ and protein yield/fed $(369.70$ and $397.29 \mathrm{~kg}$ ) in the first and second seasons, respectively. On the other hand, the minimum mean values of nitrogen uptake/fed $(16.73$ and $18.33 \mathrm{~kg})$ as well as protein yield/fed (104.55 and $114.58 \mathrm{~kg}$ ) were obtained when planting maize under unweeded control in the first and second seasons, respectively. The differences among nicosulfuron and hand hoeing twice and between pendimethalin and acetochlor as well as among acetochlor and nicosulfuron were not significant on mean values of nitrogen uptake/fed $(\mathrm{kg})$ and protein yield/fed $(\mathrm{kg})$. This result may be due to the increase in grain yield/fed. The results agree with those reported by El-Gedwy $\boldsymbol{e t}$ al. 2012; EL-Metwally et al. 2012; El-Sobky \& El-Naggar 2016 and Shaban et al. 2016.

\section{3- Interaction effect between plant population density and weed control treatments:-}

Results in Table 9 showed that mean values of nitrogen uptake/fed $(\mathrm{kg})$ and protein yield/fed $(\mathrm{kg})$ were significantly affected by the interaction between plant population density and weed control treatments in maize. But, mean values of kernels nitrogen content $(\%)$ and kernels crude protein content $(\%)$ were not significantly affected by the interaction during 2017 and 2018 seasons. It is clear that planting maize by 21000 plants/fed under mechanical weed control (hand hoeing twice) gave the highest mean values of nitrogen uptake/fed $(69.75$ and $74.82 \mathrm{~kg}$ ) and protein yield/fed (435.94 and $467.64 \mathrm{~kg}$ ) in the first and second seasons, respectively. Whereas, the minimum mean values of nitrogen uptake/fed (14.88 and $15.87 \mathrm{~kg}$ ) and protein yield/fed $(92.97$ and $99.16 \mathrm{~kg})$ in the first and second season, respectively were obtained from planting maize by 30000 plants/fed without weed control. These results are in agreement with those obtained by El-Gedwy et al. 2012; EL-Metwally et al. 2012 as well as El-Sobky and El-Naggar 2016. 
Table 8. Mean values of No. ears/fed, ear length (cm), No. of kernels/ear, weight of kernels/ear(g), shelling \%, 100-kernel weight (g), stover yield/fed (kg), grain yield/fed $(\mathrm{kg})$, biological yield/fed $(\mathrm{kg})$ and harvest index $(\%)$ as affected by interaction between plant population density and weed control treatments during 2017 and 2018 seasons.

\begin{tabular}{|c|c|c|c|c|c|c|c|c|c|c|c|c|c|c|c|c|c|c|c|c|c|}
\hline \multirow{2}{*}{$\begin{array}{l}\text { Trait } \\
\text { Season }\end{array}$} & & \multicolumn{2}{|c|}{$\begin{array}{l}\text { No. of } \\
\text { ears/fed }\end{array}$} & \multicolumn{2}{|c|}{$\begin{array}{l}\text { ear length } \\
(\mathrm{cm})\end{array}$} & \multicolumn{2}{|c|}{$\begin{array}{c}\text { No. of } \\
\text { kernels/ear }\end{array}$} & \multicolumn{2}{|c|}{$\begin{array}{c}\text { Weight of } \\
\text { kernels/ear (g) }\end{array}$} & \multicolumn{2}{|c|}{ Shelling (\%) } & \multicolumn{2}{|c|}{$\begin{array}{l}\text { 100-kernel } \\
\text { weight (g) }\end{array}$} & \multicolumn{2}{|c|}{$\begin{array}{c}\text { Stover } \\
\text { yield/fed (kg) }\end{array}$} & \multicolumn{2}{|c|}{$\begin{array}{c}\text { Grain yield/fed } \\
(\mathbf{k g})\end{array}$} & \multicolumn{2}{|c|}{$\begin{array}{c}\text { Biological } \\
\text { yield/fed } \\
(\mathrm{kg})\end{array}$} & \multicolumn{2}{|c|}{$\begin{array}{c}\text { Harvest } \\
\text { index }(\%)\end{array}$} \\
\hline & & 2017 & 2018 & 2017 & 2018 & 2017 & 2018 & 2017 & 2018 & 2017 & 2018 & 2017 & 2018 & 2017 & 2018 & 2017 & 2018 & 2017 & 2018 & 2017 & 2018 \\
\hline \multirow{5}{*}{$\begin{array}{l}18000 \\
\text { plants/fed }\end{array}$} & Pendimethalin & 21300 & 21300 & 19.25 & 20.25 & 492.80 & 522.45 & 162.87 & 182.23 & 79.85 & 81.56 & 33.05 & 34.88 & 3450 & 3825 & 2934.49 & 3180.84 & 7125 & 7725 & 41.19 & 41.18 \\
\hline & Acetochlor & 21300 & 21300 & 19.88 & 21.02 & 514.71 & 551.51 & 170.63 & 193.14 & 80.02 & 81.77 & 33.15 & 35.02 & 3675 & 3900 & 3000.75 & 3250.36 & 7425 & 7875 & 40.41 & 41.27 \\
\hline & Nicosulfuron & 21600 & 21600 & 20.57 & 21.89 & 543.40 & 573.78 & 181.60 & 206.27 & 80.24 & 82.16 & 33.42 & 35.95 & 3900 & 4200 & 3069.18 & 3327.48 & 7725 & 8250 & 39.73 & 40.33 \\
\hline & Hand hoeing twice & 21900 & 21600 & 21.52 & 23.11 & 574.20 & 619.08 & 198.21 & 229.37 & 80.87 & 82.57 & 34.52 & 37.05 & 4050 & 4200 & 3153.93 & 3467.94 & 7950 & 8400 & 39.67 & 41.29 \\
\hline & Unweeded check & 16500 & 16200 & 12.55 & 13.11 & 287.10 & 302.50 & 69.33 & 78.59 & 65.15 & 66.57 & 24.15 & 25.98 & 2700 & 2775 & 928.39 & 998.55 & 4125 & 4275 & 22.51 & 23.36 \\
\hline \multirow{5}{*}{$\begin{array}{l}21000 \\
\text { plants/fed }\end{array}$} & Pendimethalin & 22800 & 23400 & 17.77 & 19.25 & 454.40 & 496.65 & 146.63 & 166.92 & 79.31 & 80.91 & 32.27 & 33.61 & 4350 & 4500 & 3152.57 & 3519.59 & 8325 & 8850 & 37.87 & 39.77 \\
\hline & Acetochlor & 23400 & 23400 & 18.09 & 19.77 & 466.98 & 517.45 & 151.91 & 175.88 & 79.48 & 81.00 & 32.53 & 33.99 & 4500 & 4575 & 3218.94 & 3645.00 & 8550 & 9075 & 37.65 & 40.17 \\
\hline & Nicosulfuron & 23100 & 23400 & 18.24 & 20.04 & 474.50 & 525.31 & 156.92 & 182.49 & 79.67 & 81.29 & 33.07 & 34.74 & 4575 & 4650 & 3286.39 & 3719.02 & 8700 & 9225 & 37.77 & 40.31 \\
\hline & Hand hoeing twice & 23700 & 23400 & 19.02 & 20.15 & 502.92 & 542.70 & 168.58 & 190.32 & 79.98 & 81.68 & 33.52 & 35.07 & 4650 & 4725 & 3419.15 & 3798.12 & 8925 & 9375 & 38.31 & 40.51 \\
\hline & Unweeded check & 18900 & 18900 & 12.45 & 12.74 & 269.50 & 293.70 & 64.73 & 73.57 & 64.66 & 66.30 & 24.02 & 25.05 & 2925 & 3300 & 1115.39 & 1243.13 & 4650 & 5175 & 23.99 & 24.02 \\
\hline \multirow{5}{*}{$\begin{array}{l}24000 \\
\text { plants/fed }\end{array}$} & Pendimethalin & 24300 & 24600 & 16.05 & 17.77 & 387.45 & 424.08 & 122.12 & 138.97 & 77.25 & 78.81 & 31.52 & 32.77 & 4800 & 4875 & 3302.44 & 3605.56 & 9075 & 9450 & 36.39 & 38.15 \\
\hline & Acetochlor & 24600 & 25200 & 16.55 & 18.02 & 405.48 & 443.52 & 128.13 & 146.49 & 77.57 & 79.02 & 31.60 & 33.03 & 4875 & 4950 & 3374.30 & 3674.43 & 9225 & 9600 & 36.58 & 38.28 \\
\hline & Nicosulfuron & 25200 & 25200 & 17.25 & 18.53 & 415.00 & 454.86 & 131.22 & 151.47 & 78.01 & 79.25 & 31.62 & 33.30 & 4950 & 5100 & 3393.44 & 3744.56 & 9300 & 9825 & 36.49 & 38.11 \\
\hline & Hand hoeing twice & 25500 & 25200 & 17.75 & 19.00 & 435.61 & 485.04 & 138.79 & 163.94 & 78.15 & 79.99 & 31.86 & 33.80 & 4950 & 5250 & 3458.14 & 3779.53 & 9375 & 9975 & 36.89 & 37.89 \\
\hline & Unweeded check & 21000 & 20700 & 12.01 & 12.57 & 238.70 & 247.50 & 53.54 & 60.64 & 62.57 & 63.97 & 22.43 & 24.50 & 3300 & 3525 & 1220.12 & 1295.39 & 5250 & 5550 & 23.24 & 23.34 \\
\hline \multirow{5}{*}{$\begin{array}{l}27000 \\
\text { plants/fed }\end{array}$} & Pendimethalin & 25500 & 25500 & 14.22 & 16.00 & 324.72 & 383.16 & 94.23 & 115.91 & 75.42 & 76.48 & 29.02 & 30.25 & 5100 & 5325 & 2262.60 & 2638.56 & 8100 & 8775 & 27.93 & 30.07 \\
\hline & Acetochlor & 25800 & 25800 & 14.77 & 16.04 & 333.56 & 396.90 & 97.10 & 122.13 & 75.68 & 77.24 & 29.11 & 30.77 & 5100 & 5400 & 2383.92 & 2838.57 & 8250 & 9075 & 28.90 & 31.28 \\
\hline & Nicosulfuron & 26100 & 26400 & 15.09 & 16.57 & 358.75 & 413.28 & 106.01 & 129.11 & 76.24 & 77.67 & 29.55 & 31.24 & 5175 & 5475 & 2630.28 & 3087.38 & 8625 & 9450 & 30.50 & 32.67 \\
\hline & Hand hoeing twice & 26400 & 27000 & 15.55 & 17.02 & 387.35 & 430.86 & 117.13 & 136.88 & 76.55 & 78.22 & 30.24 & 31.77 & 5250 & 5550 & 2813.21 & 3050.58 & 8925 & 9450 & 31.52 & 32.28 \\
\hline & Unweeded check & 23400 & 23100 & 11.55 & 11.76 & 206.80 & 222.20 & 43.74 & 50.33 & 62.37 & 62.88 & 21.15 & 22.65 & 3525 & 3750 & 935.55 & 1037.52 & 5025 & 5400 & 18.62 & 19.21 \\
\hline \multirow{5}{*}{$\begin{array}{l}30000 \\
\text { plants/fed }\end{array}$} & Pendimethalin & 26400 & 26700 & 12.88 & 14.55 & 265.50 & 282.03 & 71.66 & 79.62 & 72.02 & 73.75 & 26.99 & 28.23 & 5400 & 5700 & 1674.47 & 1935.94 & 7725 & 8325 & 21.68 & 23.25 \\
\hline & Acetochlor & 27000 & 27300 & 13.04 & 14.88 & 274.89 & 307.34 & 71.86 & 87.71 & 72.45 & 73.99 & 26.14 & 28.54 & 5550 & 5700 & 1738.80 & 2164.21 & 7950 & 8625 & 21.87 & 25.09 \\
\hline & Nicosulfuron & 27600 & 27300 & 13.09 & 15.04 & 280.80 & 325.49 & 76.43 & 96.48 & 72.97 & 74.83 & 27.22 & 29.64 & 5625 & 5775 & 1970.19 & 2357.15 & 8325 & 8925 & 23.67 & 26.41 \\
\hline & Hand hoeing twice & 27900 & 27600 & 13.57 & 15.77 & 307.44 & 355.88 & 86.54 & 106.34 & 73.25 & 75.42 & 28.15 & 29.88 & 5700 & 5775 & 2197.50 & 2601.99 & 8700 & 9225 & 25.26 & 28.21 \\
\hline & Unweeded check & 25500 & 25800 & 11.23 & 11.62 & 192.50 & 207.90 & 40.17 & 43.64 & 61.98 & 62.57 & 20.87 & 20.99 & 3600 & 3900 & 929.70 & 985.48 & 5100 & 5475 & 18.23 & 18.00 \\
\hline \multicolumn{2}{|c|}{ L.S.D at $5 \%$} & 295 & 318 & N.S. & N.S. & 69.88 & 63.53 & 29.65 & 26.25 & N.S. & N.S. & 3.44 & 3.11 & 528 & 476 & 417.12 & 386.30 & 975 & 890 & N.S. & N.S. \\
\hline
\end{tabular}


Table 9. Mean values of kernels nitrogen content (\%), kernels crude protein content (\%), nitrogen uptake/fed $(\mathrm{kg})$ and protein yield/fed $(\mathrm{kg})$ as affected by plant population density, weed control treatments and their interaction during 2017 and 2018 seasons.

\begin{tabular}{|c|c|c|c|c|c|c|c|c|c|}
\hline \multirow{2}{*}{\multicolumn{2}{|c|}{ Trait }} & \multicolumn{2}{|c|}{$\begin{array}{c}\text { Kernels nitrogen } \\
\text { content } \\
(\%)\end{array}$} & \multicolumn{2}{|c|}{$\begin{array}{c}\text { Kernels crude } \\
\text { protein content } \\
(\%)\end{array}$} & \multicolumn{2}{|c|}{$\begin{array}{l}\text { Nitrogen } \\
\text { uptake/fed } \\
(\mathrm{kg})\end{array}$} & \multicolumn{2}{|c|}{$\begin{array}{l}\text { Protein yield/fed } \\
\text { (kg) }\end{array}$} \\
\hline & & 2017 & 2018 & 2017 & 2018 & 2017 & 2018 & 2017 & 2018 \\
\hline \multicolumn{10}{|c|}{ Plant population density (plants/fed) } \\
\hline \multicolumn{2}{|l|}{18000} & 1.95 & 1.89 & 12.16 & 11.84 & 52.16 & 54.85 & 325.99 & 342.82 \\
\hline \multicolumn{2}{|l|}{21000} & 1.94 & 1.89 & 12.10 & 11.80 & 56.21 & 61.25 & 351.30 & 382.84 \\
\hline \multicolumn{2}{|l|}{24000} & 1.88 & 1.83 & 11.76 & 11.45 & 56.61 & 59.87 & 353.82 & 374.20 \\
\hline \multicolumn{2}{|l|}{27000} & 1.82 & 1.79 & 11.39 & 11.18 & 40.88 & 45.85 & 255.50 & 286.59 \\
\hline \multicolumn{2}{|l|}{30000} & 1.75 & 1.72 & 10.91 & 10.78 & 30.03 & 34.95 & 187.71 & 218.47 \\
\hline \multicolumn{2}{|c|}{ L.S.D at $5 \%$} & N.S. & N.S. & N.S. & N.S. & 2.44 & 2.12 & 15.23 & 13.25 \\
\hline \multicolumn{10}{|c|}{ Weed control treatments } \\
\hline \multicolumn{2}{|c|}{ Pendimethalin } & 1.89 & 1.85 & 11.84 & 11.55 & 50.96 & 55.39 & 318.47 & 346.20 \\
\hline \multicolumn{2}{|c|}{ Acetochlor } & 1.91 & 1.86 & 11.96 & 11.63 & 52.95 & 58.27 & 330.93 & 364.21 \\
\hline \multicolumn{2}{|c|}{ Nicosulfuron } & 1.94 & 1.88 & 12.13 & 11.73 & 56.11 & 61.22 & 350.68 & 382.62 \\
\hline \multicolumn{2}{|c|}{ Hand hoeing twice } & 1.95 & 1.89 & 12.21 & 11.84 & 59.15 & 63.57 & 369.70 & 397.29 \\
\hline \multicolumn{2}{|c|}{ Unweeded check } & 1.63 & 1.65 & 10.19 & 10.30 & 16.73 & 18.33 & 104.55 & 114.58 \\
\hline \multicolumn{2}{|c|}{ L.S.D at 5\% } & N.S. & N.S. & N.S. & N.S. & 3.48 & 2.98 & 21.75 & 18.65 \\
\hline \multicolumn{10}{|c|}{ Plant density X Weed control } \\
\hline \multirow{5}{*}{$\begin{array}{l}18000 \\
\text { plants/fed }\end{array}$} & Pendimethalin & 1.98 & 1.92 & 12.38 & 12.00 & 58.10 & 61.07 & 363.14 & 381.70 \\
\hline & Acetochlor & 2.00 & 1.92 & 12.50 & 12.00 & 60.02 & 62.41 & 375.09 & 390.04 \\
\hline & Nicosulfuron & 2.04 & 1.95 & 12.75 & 12.19 & 62.61 & 64.89 & 391.32 & 405.54 \\
\hline & Hand hoeing twice & 2.05 & 1.99 & 12.81 & 12.44 & 64.66 & 69.01 & 404.10 & 431.33 \\
\hline & Unweeded check & 1.66 & 1.69 & 10.38 & 10.56 & 15.41 & 16.88 & 96.32 & 105.47 \\
\hline \multirow{5}{*}{$\begin{array}{l}21000 \\
\text { plants/fed }\end{array}$} & Pendimethalin & 1.97 & 1.92 & 12.31 & 12.00 & 62.11 & 67.58 & 388.16 & 422.35 \\
\hline & Acetochlor & 1.98 & 1.94 & 12.38 & 12.13 & 63.74 & 70.71 & 398.34 & 441.96 \\
\hline & Nicosulfuron & 2.04 & 1.95 & 12.75 & 12.19 & 67.04 & 72.52 & 419.01 & 453.26 \\
\hline & Hand hoeing twice & 2.04 & 1.97 & 12.75 & 12.31 & 69.75 & 74.82 & 435.94 & 467.64 \\
\hline & Unweeded check & 1.65 & 1.66 & 10.31 & 10.38 & 18.40 & 20.64 & 115.02 & 128.97 \\
\hline \multirow{5}{*}{$\begin{array}{l}24000 \\
\text { plants/fed }\end{array}$} & Pendimethalin & 1.92 & 1.86 & 12.00 & 11.63 & 63.41 & 67.06 & 396.29 & 419.15 \\
\hline & Acetochlor & 1.94 & 1.87 & 12.13 & 11.69 & 65.46 & 68.71 & 409.13 & 429.45 \\
\hline & Nicosulfuron & 1.95 & 1.88 & 12.19 & 11.75 & 66.17 & 70.40 & 413.57 & 439.99 \\
\hline & Hand hoeing twice & 1.97 & 1.90 & 12.31 & 11.88 & 68.13 & 71.81 & 425.78 & 448.82 \\
\hline & Unweeded check & 1.63 & 1.65 & 10.19 & 10.31 & 19.89 & 21.37 & 124.30 & 133.59 \\
\hline & Pendimethalin & 1.85 & 1.81 & 11.56 & 11.31 & 41.86 & 47.76 & 261.61 & 298.49 \\
\hline & Acetochlor & 1.87 & 1.82 & 11.69 & 11.38 & 44.58 & 51.66 & 278.62 & 322.89 \\
\hline 2/000 & Nicosulfuron & 1.88 & 1.84 & 11.75 & 11.50 & 49.45 & 56.81 & 309.06 & 355.05 \\
\hline & Hand hoeing twice & 1.90 & 1.84 & 11.88 & 11.50 & 53.45 & 56.13 & 334.07 & 350.82 \\
\hline & Unweeded check & 1.61 & 1.63 & 10.06 & 10.19 & 15.06 & 16.91 & 94.14 & 105.70 \\
\hline & Pendimethalin & 1.75 & 1.73 & 10.94 & 10.81 & 29.30 & 33.49 & 183.14 & 209.32 \\
\hline & Acetochlor & 1.78 & 1.75 & 11.13 & 10.94 & 30.95 & 37.87 & 193.44 & 236.71 \\
\hline $\begin{array}{l}30000 \\
\text { nlants/fed }\end{array}$ & Nicosulfuron & 1.79 & 1.76 & 11.19 & 11.00 & 35.27 & 41.49 & 220.42 & 259.29 \\
\hline & Hand hoeing twice & 1.81 & 1.77 & 11.31 & 11.06 & 39.77 & 46.06 & 248.59 & 287.85 \\
\hline & Unweeded check & 1.60 & 1.61 & 10.00 & 10.06 & 14.88 & 15.87 & 92.97 & 99.16 \\
\hline & S.D at 5\% & N.S. & N.S. & N.S. & N.S. & 7.78 & 6.66 & 48.63 & 41.70 \\
\hline
\end{tabular}




\section{References:}

A.O.A.C. (1990). Official Methods of Analysis Association of Official Analysis Chemists, $13^{\text {th }}$ Ed., Washington, D. C., U. S. A.

Abouziena, H. F.; I. M. El-Metwally and E. R. ElDesoki (2008). Effect of plant spacing and weed control treatments on maize yield and associated weeds in Sandy Soils. Am-Euras. J. Agric. \& Environ. Sci., 4 (1): 9-17.

Acciares, H. A. and M. S. Zuluaga (2006). Effect of plant row spacing and herbicide use on weed aboveground biomass and corn grain yield. Planta Daninha, 24 (2): 287-293.

Ahmed, S. E.; H. M. Shams; I. M. EL-Metwally; M. N. Shehata and M. A. EL-Wakeel (2008). Efficiency of some weed control treatments on growth, yield and its attributes of maize (Zea mays L.) plants and associated weeds. J. Agric. Sci. Mansoura Univ., 33 (7): 4777-4789.

Amare, T.; A. Mohammed; M. Negeri and F. Sileshi (2019). Effect of weed control methods on weed density and maize (Zea mays, L.) yield in West Shewa Orimia, Ethiopia. Afr. J. Plant Sci., 9 (1): 8-12.

Amiri, Z.; A. Tavakkoli and M. Rastgoo (2014). Responses of corn to plant density and weed interference period. Middle-East J. Sci. Res., 21 (10): 1746-1750.

Black, C. A. and D. D. Evans (1965). Methods of Soil Analysis. Amer. Soc. of Agron., Inc. Pub. Madison, Wisconsin, USA.

El-Gedwy, E. M. M.; M. R. Gomaa and S. A. H. Allam (2012). Maize yield as affected by periods of weed control and plant densities. LAP Lambert Academic Publishing, ISBN 9783-8484-2443-6, paperback, 216 PP.

El-Hosary, A. A.; G. Y. Hammam; E. M. M. ElGedwy and M. E. Sidi (2019). Response of white maize hybrids to plant densities and nitrogen fertilizer rates. Annals of Agric. Sci., Moshtohor, 57 (2): 333-350.

EL-Metwally, I. M.; M. S. Abd El- Salam; R. M. H. Tagour and H. F. Abouziena (2012). Efficiency of plant population and reduced herbicides rate on maize productivity and associated weeds. J. App. Sci. Res., 8 (4): 23422349.

El-Sobky, E. E. A. and N. Z. A. El-Naggar (2016). Effect of weed control treatments and planting density in maize (Zea mays, L.). Egypt. J. Agron., 38 (1): 55-77.

Eyasu, E.; D. Shanka; D. Dalga and E. Elias (2018). Yield response of maize (Zea mays, L.) varieties to row spacing under irrigation at Geleko, Ofa Woreda, Wolaita Zone, Southern Ethiopia. J. Exp. Agric. Inter., 20 (1): 1-10.

Gobeze, Y. L.; G. M. Ceronio and L. D. V. Rensburg (2016). Effect of spatial arrangements of row spacing and plant density on water use and water use efficiency of maize under irrigation. J. Nat. Sci. Res., 6 (1): 13-22.

Gomez, K. A., and A. A. Gomez (1984). Statistical Procedures for Agricultural Research. $2^{\text {nd }}$, (ed). John Wiley and Sons, NY, U.S.A.

Knezevic, M.; M. Durkic, I. Knezevic and $Z$. Loncaric (2003). Effects of pre- and postemergence weed control on weed population and maize in different tillage systems. Plant Soil Environ., 49 (5): 223-229.

Mandić, V.; Z. Bijelić; V. Krnjaja; Z. Tomić; A. S. Sebić; A. Stanojković and V. C. Petrović (2016). The effect of crop density on maize grain yield. Biotech. Animal Husb., 32 (1): 8390.

Marin, C. and J. Weiner (2014). Effects of density and sowing pattern on weed suppression and grain yield in three varieties of maize under high weed pressure. Weed Research, 54: 467474.

Michigan State University (1983). MSTAT-C: Micro-computer Statistical Program, Version 2. Michigan State University, East Lansing.

Nogueira, C. H. P. and N. M. Correia (2016). Selectivity of herbicides bentazon and nicosulfuron for crotalaria juncea intercropped with maize culture. Planta Daninha, 34 (4): 747-757.

Oerke, E. C. (2006). Crop losses to pests. J. Agric. Sci., 144: 31-43.

Pacanoski, Z.; Z. Svečnjak and A. Saliji (2015). Herbicides impact on weed control and injury of maize and climbing bean grown in an intercropping system. Herbologia, 15 (2): 55: 76

Rahman, M. M.; S. K. Paul and M. M. Rahman (2016). Effects of spacing and nitrogen levels on yield and yield contributing characters of maize. J. Bangladesh Agril. Univ., 14 (1): 4348.

Ramesh Babu, T. and T. Senthivel (2019). Influence of Plant Spacing and Weed Management Practices on the Growth and Yield of Hybrid Maize. Int. J. Curr. Microbiol. App. Sci., 8 (3): 2272-2283.

Rastgordani, F.; A. Ahmadi; N. A. Sajedi (2013). The influence of mechanical and chemical methods on weeds control in maize. Tech. J Engin. \& App. Sci., 3 (5): 3858-3863.

Shaban, Sh. A.; S. A. Safina; Z. R. Yehia and R. G. M. Abo El-Hassan (2016). Effect of some herbicides on quality of maize grains and the following winter crops. Egypt . J. Appl. Sci., 31 (1): $1-14$

Shaban, Sh. A.; Z. R. Yehia, S. A. Safina and R. G. Abo El-Hassan (2015). Effect of some maize herbicides on weeds and yield and residual effect on some following crops (wheat and broad bean). Am-Euras. J. Agric. \& Environ. Sci., 15 (6): 1004-1011. 
Sharanabasappa, H. C.; M. A. Basavanneppa and B. G. Koppalkar (2017). Productivity of quality protein maize (Zea mays, L.) and soil fertility as influenced by plant population and fertilizer levels under irrigated ecosystem. Int. J. Adv. Biol. Res., 7 (3): 504-508.

Sidi, M. E.; A. A. El-Hosary; G. Y. Hammam; E. M. El-Gedwy and A. A. A. El-Hosary (2019). Maize hybrids yield potential as affected by plant population density in Qalyubia, Egypt. Bioscience Res., 16 (2): 1565-1576.

Simić, M.; M. Brankov and V. Dragičević (2017). Effects of nitrogen form, row spacing and herbicide application on weed control and maize biomass production. Herbologia, 16 (2): 55: 76.

Stickler, F.C. (1964). Row Width and Plant Production Studies. Sixth edition, Iowa state Univ. Press, Ames. U.S.A.

Tahir, M.; M. R. Javed; A. Tanveer; M. A. Nadeem; A. Wasaya; S. A. H. Bukhari and J. Ur-Rehman (2009). Effect of Different Herbicides on Weeds, Growth and Yield of
Spring Planted Maize (Zea mays, L.). Pak. J. Life Soc. Sci., 7 (2): 168-174.

Tesfay, A.; M. Amin and N. Mulugeta (2014). Management of weeds in maize (Zea mays, L.) through various pre and post emergency herbicides. Adv. Crop Sci. Tech., 2 (5): 151155.

Teymoori, M.; M. A. Baghestani; E. Zand; H. Madani and S. Mafakheri (2013). Weed management in maize field by chemical, mechanical and cultural methods. Res. on Crops 14 (3): 729-735.

Tyagi, S.; S. K. Mandal; B. Kumar; S. Kumar and V. Kumar (2017). Efficacy of different herbicides on weed dynamics, yields attributes and yield of maize. Bull. Env. Pharmacol. Life Sci., 6 (1): 498-503.

Zeleke, A.; G. Alemayehu and G. S. Yihenew (2018). Effects of planting density and nitrogen fertilizer rate on yield and yield related traits of maize (Zea mays, L.) in Northwestern, Ethiopia. Adv. Crop Sci. Tech., 6 (2): 1-5 


\section{تأثير الكثافة النباتية ومعاملات مقاومة الحثائش على محصول الذرة الثامية وإلحثائش المصاحبة السعيد محمد محمود الجدوي \\ قسم المحاصيل ـ كلية الزراعة ـ جامعة بنها ـ مصر.}

أجريت تجربتان حقلينان في مزرعة مركز البحوث و التجارب الزراعية بكلية الزراعة بمشتهر جامعة بنها (مركز طوخ ـ محافظة القليوبية ـ

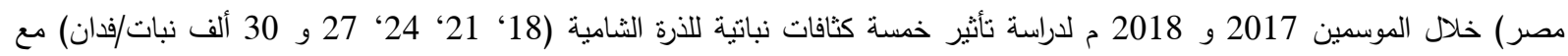

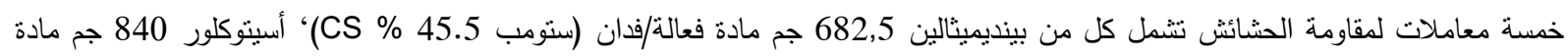

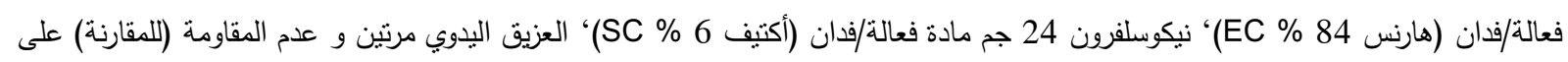
محصول الذرة الثامية (هجين فردي أبيض 2036 شركة مصر هاب تلك الدولية للبذور) والحشائش المصاحبة. ويمكن تلخيص أهم النتائج فيما يلي:- ماد أدت زيادة الكثافة النباتية من 18 إلى 30 ألف نبات/فدان إلى تقليل الوزن الغض و الجاف للحشائش الحولية المختلفة مع حدوث زيادة معنوية

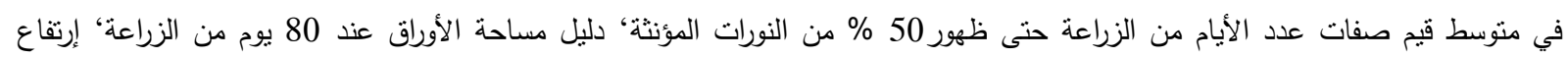

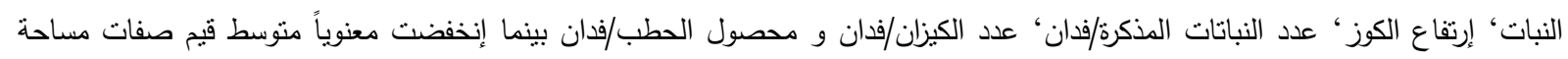

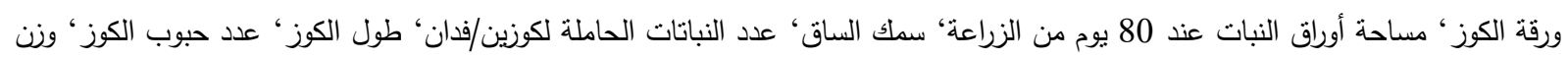

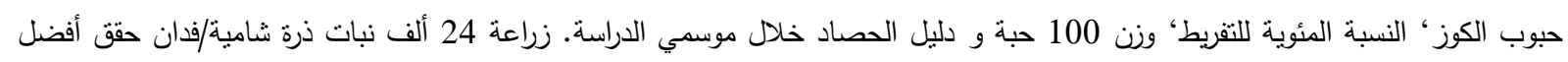

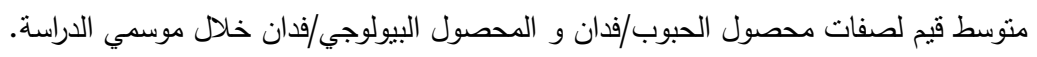

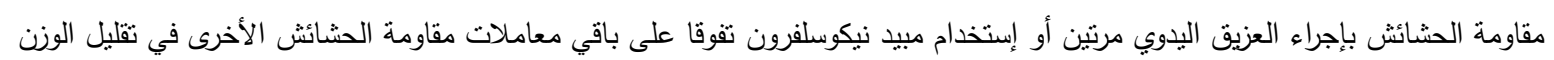

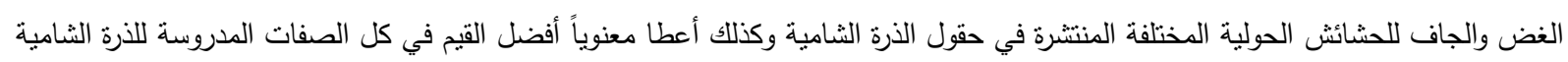

مع عدم وجود فروق معنوية بينهما خلال موسمي التجربة.

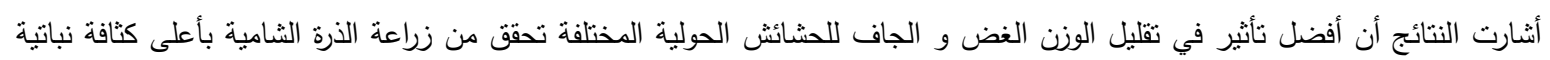

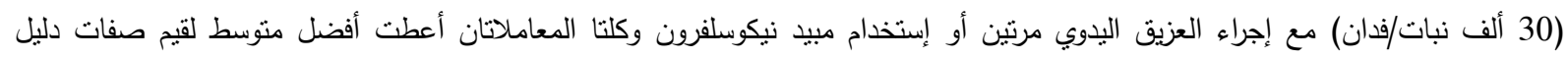

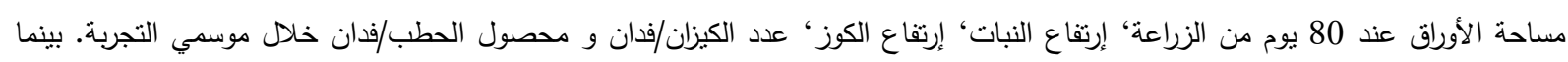

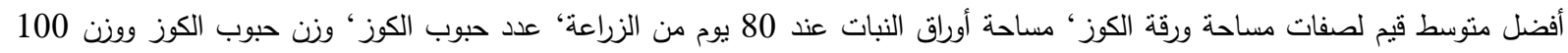

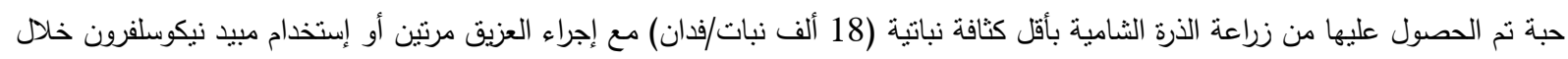

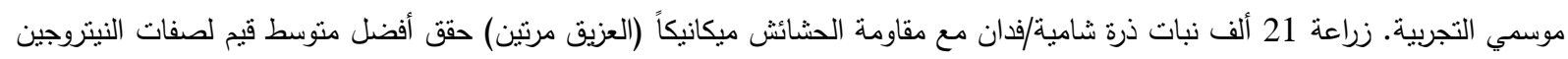

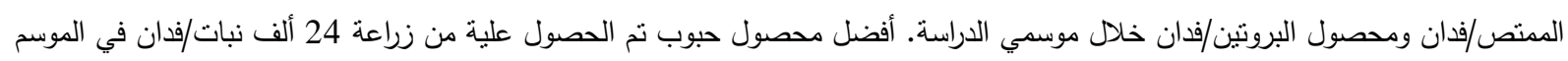

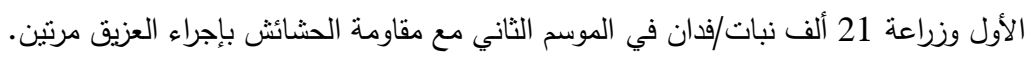

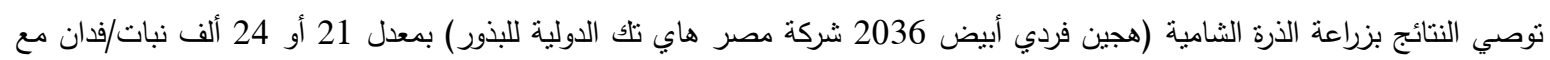

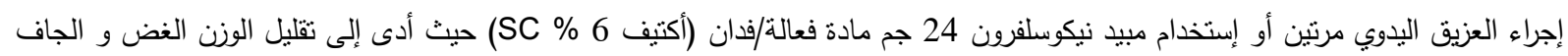
للحشائش الحولية المختلفة وزاد محصول الحبوب/فئان. 